\title{
WATER-RESOURCES INVESTIGATIONS OF THE U. S. GEOLOGICAL SURVEY IN WYOMING, OCTOBER 1976 TO SEPTEMBER 1977
}

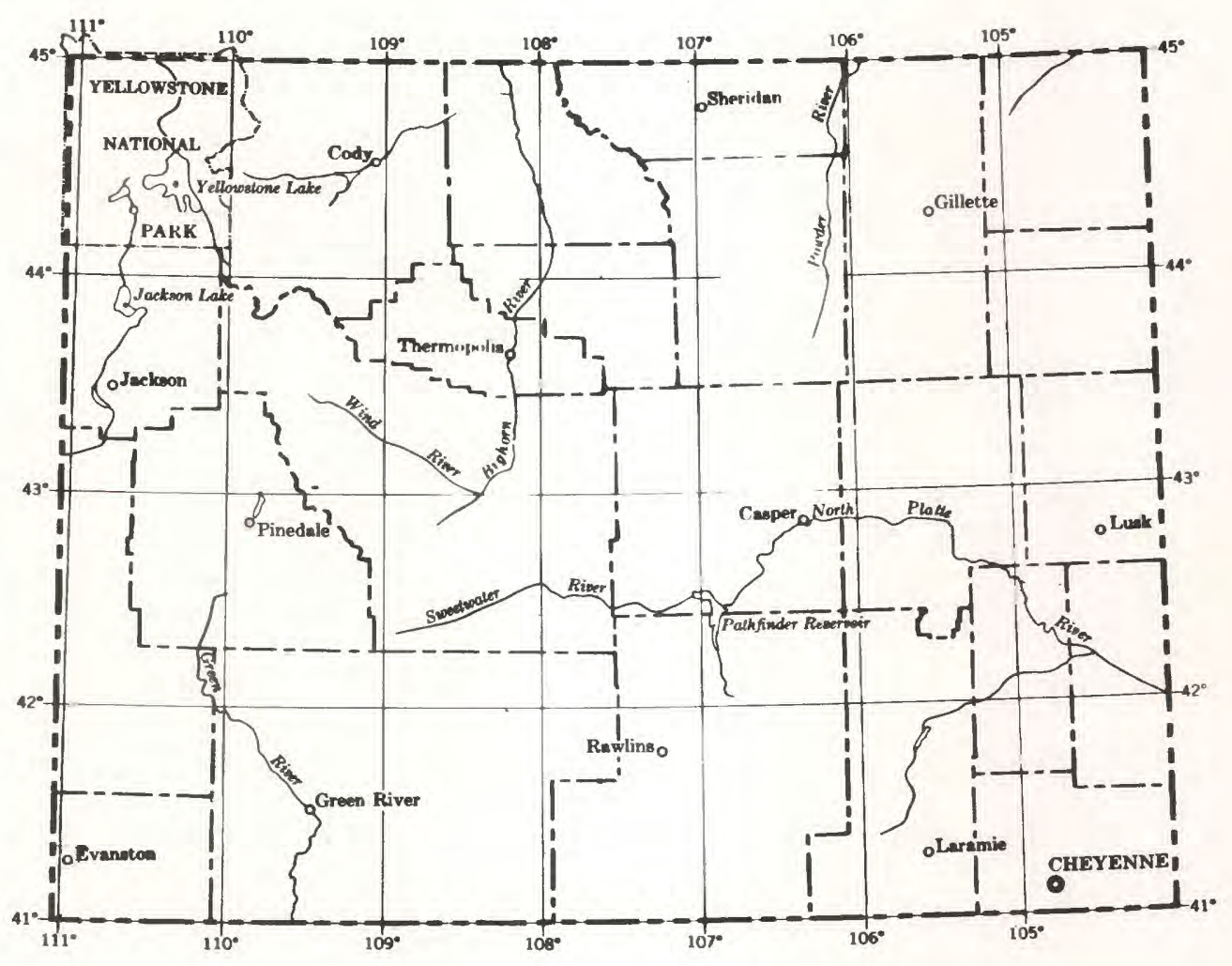

Prepared by

UNITED STATES DEPARTMENT OF THE INTERIOR GEOLOGICAL SURVEY

OPEN-FILE REPORT 77-222

FEBRUARY 1977 


\section{UNITED STATES \\ DEPARTMENT OF THE INTERIOR \\ GEOLOGICAL SURVEY}

WATER-RESOURCES INVESTIGATIONS OF THE

U.S. GEOLOGICAL SURVEY IN WYOMING,

OCTOBER 1976 TO SEPTEMBER 1977

By U.S. Geological Survey, Water Resources Division

Open-File Report 77-222

Cheyenne, Wyoming

February 1977 
UNITED STATES DEPARTMENT OF THE INTERIOR

Cecil D. Andrus, Secretary

GEOLOGICAL SURVEY

V. E. McKelvey, Director

COOPERATING AGENCIES

State Agencies

Wyoming Department of Agriculture

Wyoming Department of Economic Planning and Development

Wyoming Department of Environmental Quality

Wyoming Highway Department

Wyoming State Engineer

Wyoming Water Resources Research Institute

County

Teton

Municipalities

City of Cheyenne

City of Riverton

Federal Agencies

Bureau of Land Management

Bureau of Reclamation

Corps of Engineers

Energy Research and Development Administration

Environmental Protection Agency

National Park Service 
Introduction-- 1

Data-collection activities-- 2

Streamflow and reservoir stations-_- 2

Peak-flow partial-record stations-_- 2

Chemical-quality stations-_- 2

Sediment stations-_- 2

Observation we11s-C 2

Water-resources appraisal projects-_-_ 42

Flood investigations in Wyoming-_- 42

Flood-hazard information, House Document 465- 42

Water resources of Weston County, Wyoming- 42

Monitoring waste-water effluent in Yellowstone and

Grand Teton National Parks, Wyoming-_- 44

Water and its relation to economic development in the

Green River and Great Divide basins in Wyoming--_- 44

Impacts of economic development and water use on water

resources in the Hanna basin in Wyoming-_- 44

Water resources of the Powder River structural basin

in Wyoming in relation to energy development-- 45

Hydrology of Paleozoic rocks in the Powder River basin and adjacent areas, northeastern Wyoming--_-_-_- 45

Evaluation of selected Paleozoic and flood-plain aquifers in the Bighorn basin, north-central Wyoming--- 46

Algal-growth potential of principal North Platte River reservoirs in Wyoming-Preliminary digital model of the Arikaree aquifer in

the Sweetwater River basin, central Wyoming----------

Quantitative study of the Tertiary aquifers in southern Laramie County, Wyoming--

Availability of ground water from the Cretaceous and Tertiary aquifers of the Fort Union Coal. Region--------

Runoff and sediment yield from rainfall simulation-------

Geochemical survey of waters of the western coal regions--

Reconnaissance techniques for evaluating the rehabilitation potential of energy lands--

Sorption of residual organic substances in retort waters by spent oil-shale residues-

Hydrology of the Madison aquifer- 


\section{ILLUSTRATIONS}

Figures 1-5. Maps showing location of surface-water data sites in:

1. The Yellowstone River, Clarks Fork

Yellowstone River, and Bighorn River basins----

2. The Tongue River, Powder River, Belle Fourche

River, and Cheyenne River basins-_-_-_-_-_--- 4

3. The Niobrara River and Platte. River basins------ 5

4. The Green River and Bear River basins--_-_------- 6

5. The Snake River basin--_-_-_-

6-9. Maps showing locations of observation wells in:

6. The Yellowstone River, Clarks Fork

Yellowstone River, and Bighorn River basins----

7. The Tongue River, Powder River, Belle Fourche

River, and Cheyenne River basins-_-_-_-_-_ 30

8. The Niobrara River and Platte River basins------ 31

9. The Green River and Bear River basins-_-_-_-_-_ 32

10. Water-resources appraisa1 projects-_-_-_-_-_-_ 43

\section{TABLES}

Table 1. Streamflow and reservoir stations-_-_-_-_-_-_-_-_-_-

2. Peak-flow partial-record stations-_-_-_-_-_-_-_-_-_-

3. Chemical-quality stations-_-_-_-_-_-_-_-_-_-_-_--

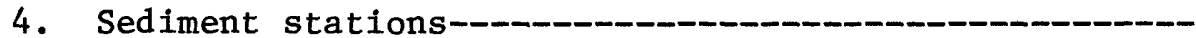

5. Observation wells-_-_-_-_- 
WATER-RESOURCES INVESTIGATIONS OF THE

U.S. GEOLOGICAL SURVEY IN WYOMING,

OCTOBER 1976 TO SEPTEMBER 1977

\section{INTRODUCTION}

The U.S. Geological Survey, in cooperation with the State of Wyoring, Teton County, the cities of Cheyenne and Riverton, and other Federal agencies, have five data-collection activities and 18 water-resources appraisal projects under way in Wyoming during fiscal year 1977 (October 1, 1976, through September 30, 1977).

The data-collection activities include: (1) Continuous records of streamflow and reservoir storage; (2) peak-flow information at partialrecord sites; (3) sampling and chemical analyses of water from streams and wells; (4) sampling and sediment analysis of surface water; and (5) measurements of water levels in wells. This report contains lists of monitoring sites for these five data-collection activities.

The water-resources appraisal projects include: (1) Flood investigations in Wyoming; (2) Flood-hazard information, House Document 465; (3) Water resources of Weston County, Wyoming; (4) Monitoring waste-water effluent in Yellowstone and Grand Teton National Parks, Wyoming;

(5) Water and its relation to economic development in the Green River and Great Divide basins in Wyoming; (6) Impacts of economic development and water use on water resources in the Hanna basin in Wyoming; (7) Water resources of the Powder River structural basin in Wyoming in relation to energy development; (8) Hydrology of Paleozoic rocks in the Powder River basin and adjacent areas, northeastern Wyoming; (9) Evaluation of selected Paleozoic and flood-plain aquifers in the Bighorn basin, north-central Wyoming; (10) Algal-growth potential of principal North Platte River reservoirs in Wyoming; (11) Preliminary digital model of the Arikaree aquifer in the Sweetwater River basin, central Wyoming; (12) Quantitative study of the Tertiary aquifers in southern Laramie County, Wyoming; (13) Availability of ground water from the Cretaceous and Tertiary aquifers of the Fort Union Coal Region; (14) Runoff and sediment yield from rainfall simulation; (15) Geochemical survey of waters of the western coal regions; (16) Reconnaissance techniques for evaluating the rehabilitation potential of energy lands; (17) Sorption of residual organic substances in retort waters by spent oil- shale residues; and (18) Hydrology of the Madison aquifer. 
The purpose of this report is to describe the water-resources rork being done in Wyoming, especially in the coal and oil-shale developrent areas. It is one phase of an effort to coordinate the water-resources investigations of the U.S. Geological Survey with those of other organizations. Additional information about the water-resources program of the Geological Survey or closer coordination of the water-resources studies may be obtained by contacting the District Chief, Water Resources Division, U.S. Geological Survey, 4020 House Avenue, P.0. Box 2087, Cheyenne, Wyoming 82001. The commercial telephone number is 307-778-2220, extension 2111, and the FTS number is 328-2111.

\section{DATA-COLLECTION ACTIVITIES}

Basic data currently being collected are shown as follows: Talle 1, Streamflow and reservoir stations; table 2, peak-flow partial-record stations; table 3, chemical-quality stations; table 4, sediment stations; and table 5, observation wells.

Stations in the first four tables are listed in downstream order. Identification numbers have been assigned to conform with the standard downstream order for 1isting stations within each hydrologic region. The location of each data site is given in the tables.

Observation wells are listed in numerical order by counties. The we11-numbering procedure used is based on the U.S. Land Grant System. The first segment of the number is the township (north); the second number segment is the range (west); the third number segment is the section, which is followed by a first letter designating the quarter section, a second letter, if shown, designating the quarter-quarter section, etc., $\left(A-N E \frac{1}{4}, B-N W^{\frac{1}{4}}, \mathrm{C}-\mathrm{SW} \frac{1}{4}, \mathrm{D}-\mathrm{SE} \frac{1}{4}\right)$. We11 30-108-05BCD2, for examp1e, is in

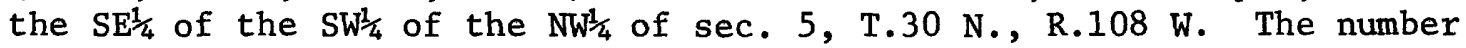
2 indicates a second well in the quarter-quarter-quarter section. "ells shown in Fremont County have an additional uppercase letter that begins the number. This letter designates the quadrant of the Wind River Meridian and Base Line System. The quadrants are lettered A, B, C, and $D$ in a counter-clockwise direction beginning with $A$ in the northeast quadrant.

The headings of the columns in the five tables are slightly different to accomodate the type of site in each 1ist. In order to include the variety of information required by the many users of the 1ists, abbreviations and codes were used to conserve space in the tables. Explanations of the abbreviations and codes are given preceeding each table.

The locations of surface-water data sites are shown in figures 1-5. Observation well locations are shown in figures 6-9. 


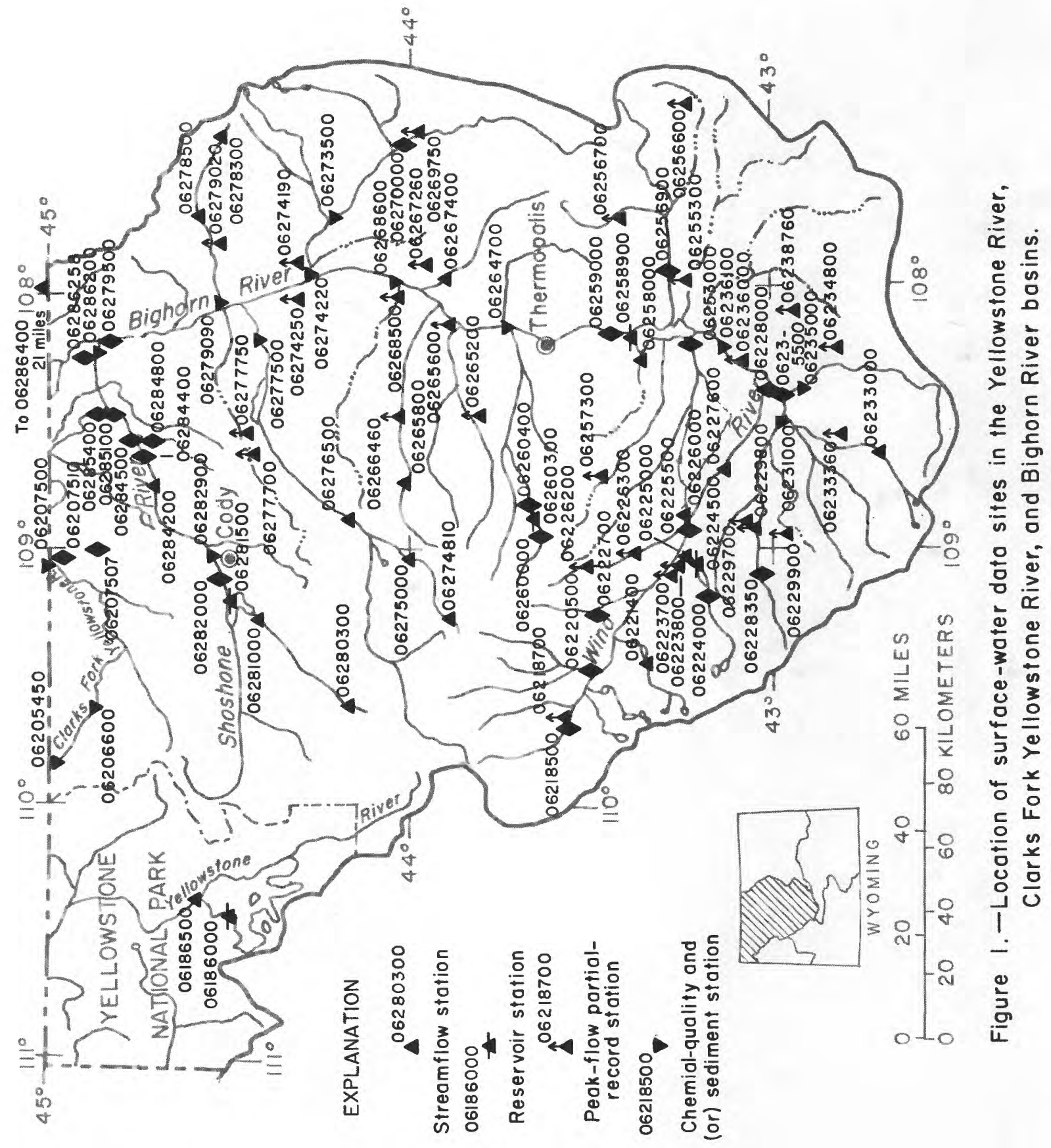




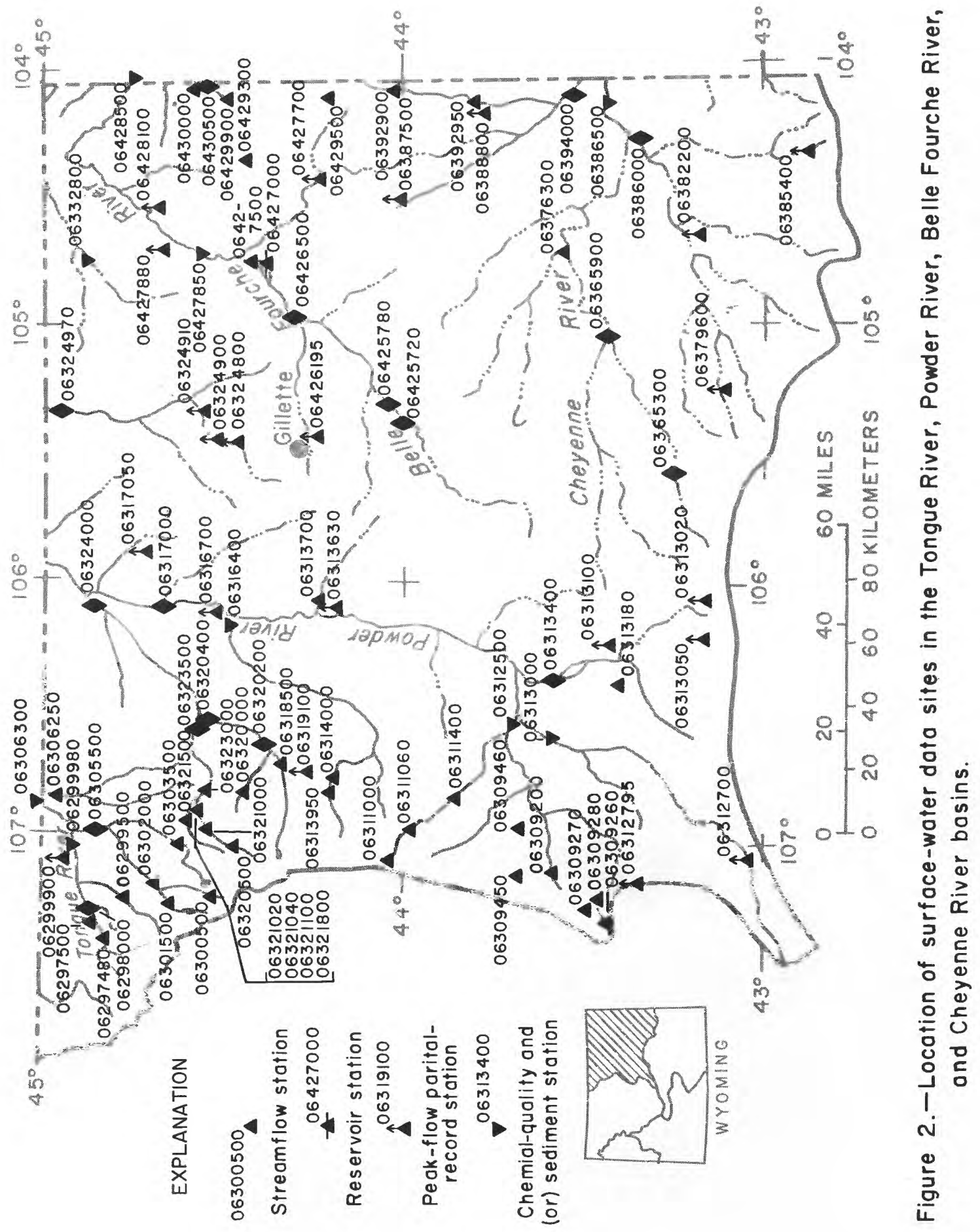




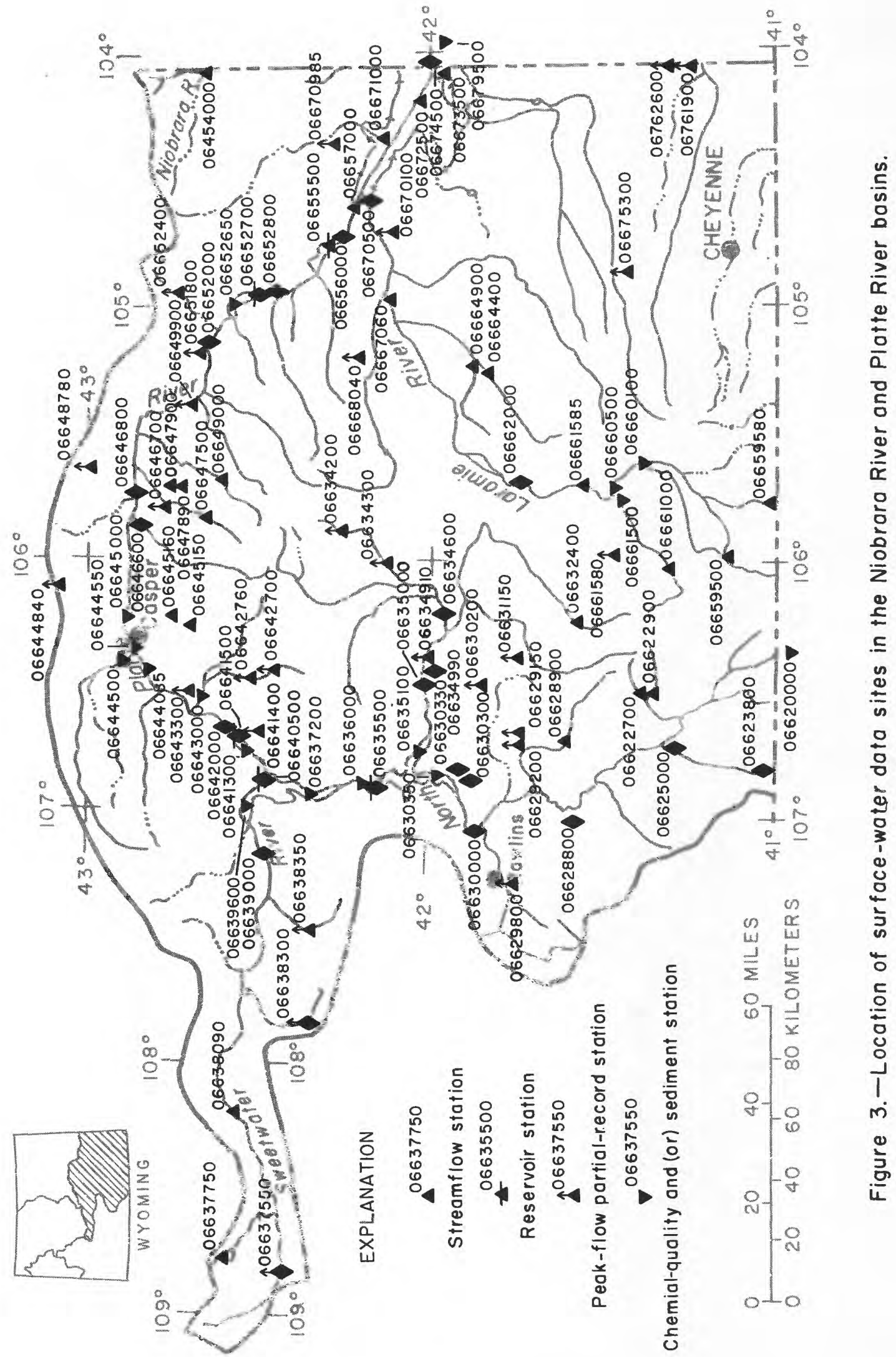




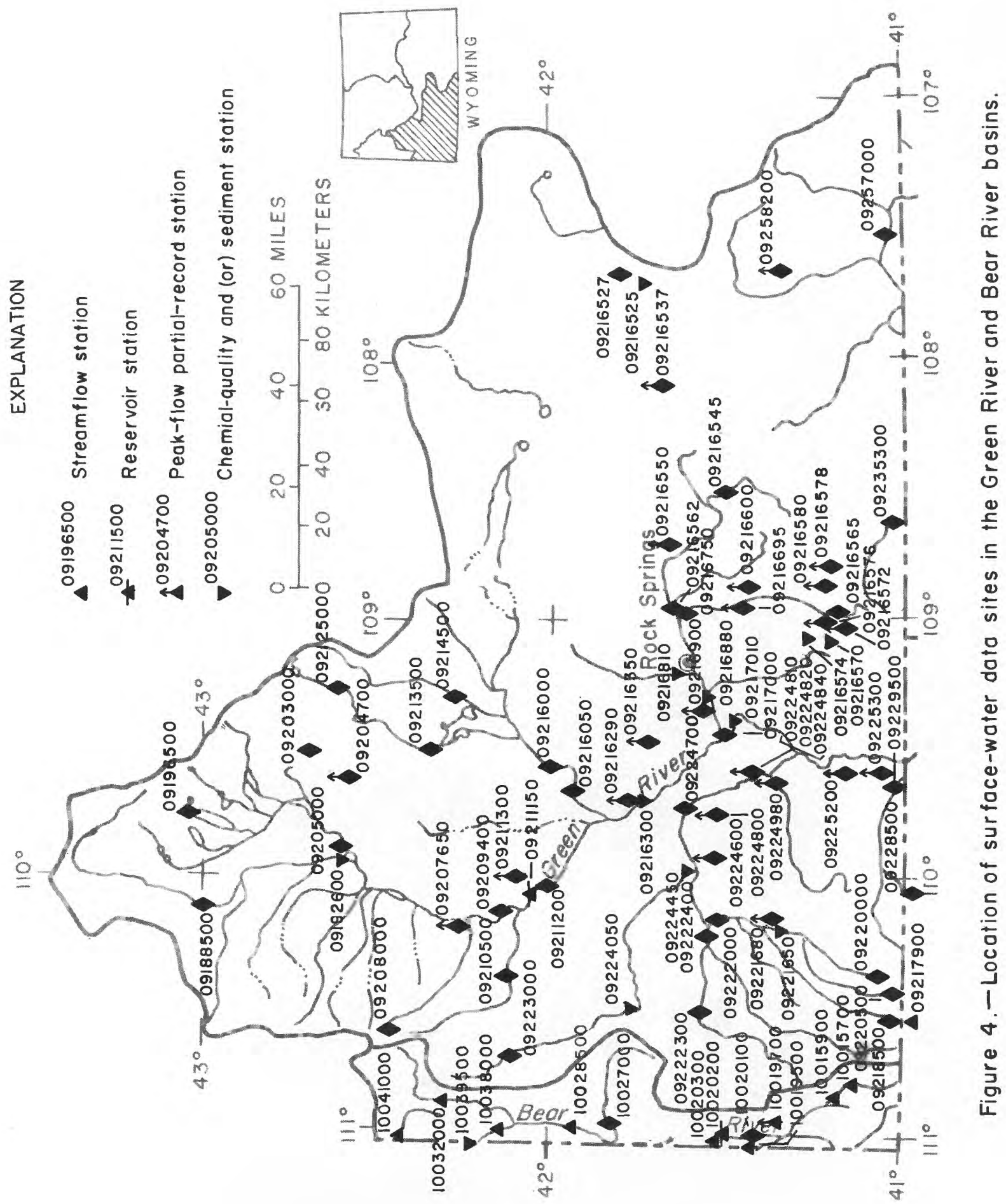




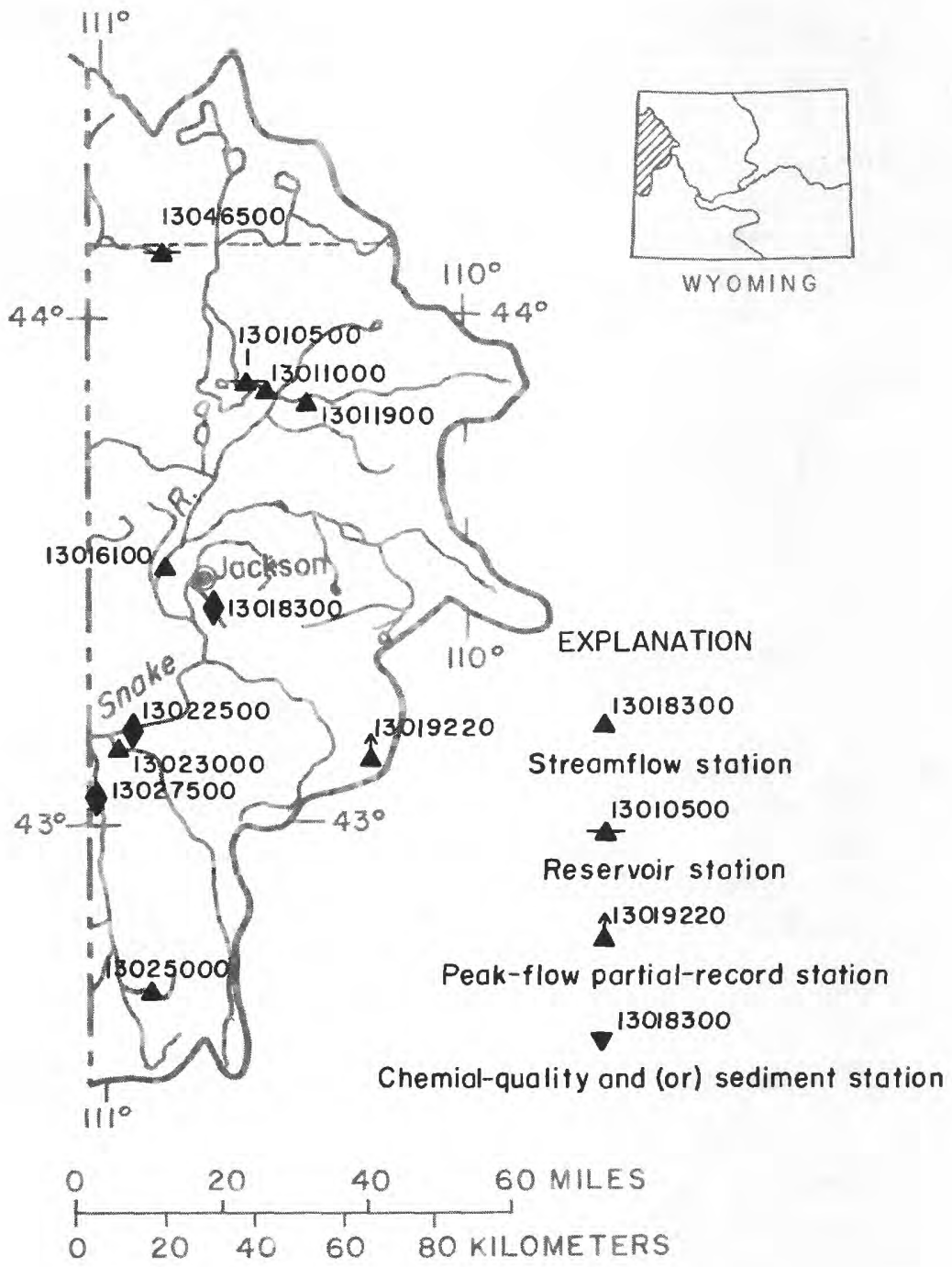

Figure 5.-Location of surface-water data sites in the Snake River basin. 
Explanation of abbreviations and codes used in table 1.

Purpose: B, bench-mark or long-term-trend station

C, current-purpose station such as accounting, operation, forecasting, disposal, water quality, compact or legal, research or special study

$\mathrm{H}$, hydrologic station

$P$, principal-stream station

$R$, regulated station

Period of Record: The dates given are the calendar years in which records began or ended. Breaks of less than a year are not shown.

Gage Equipment: D, digital recorder

G, graphic recorder

$M$, manometer gage

0 , observer record only

$\mathrm{T}$, pressure-transducer gage

$W$, well gage

Current Record Type: S, seasonal operation (no winter records)

$\mathrm{Y}$, full-year operation

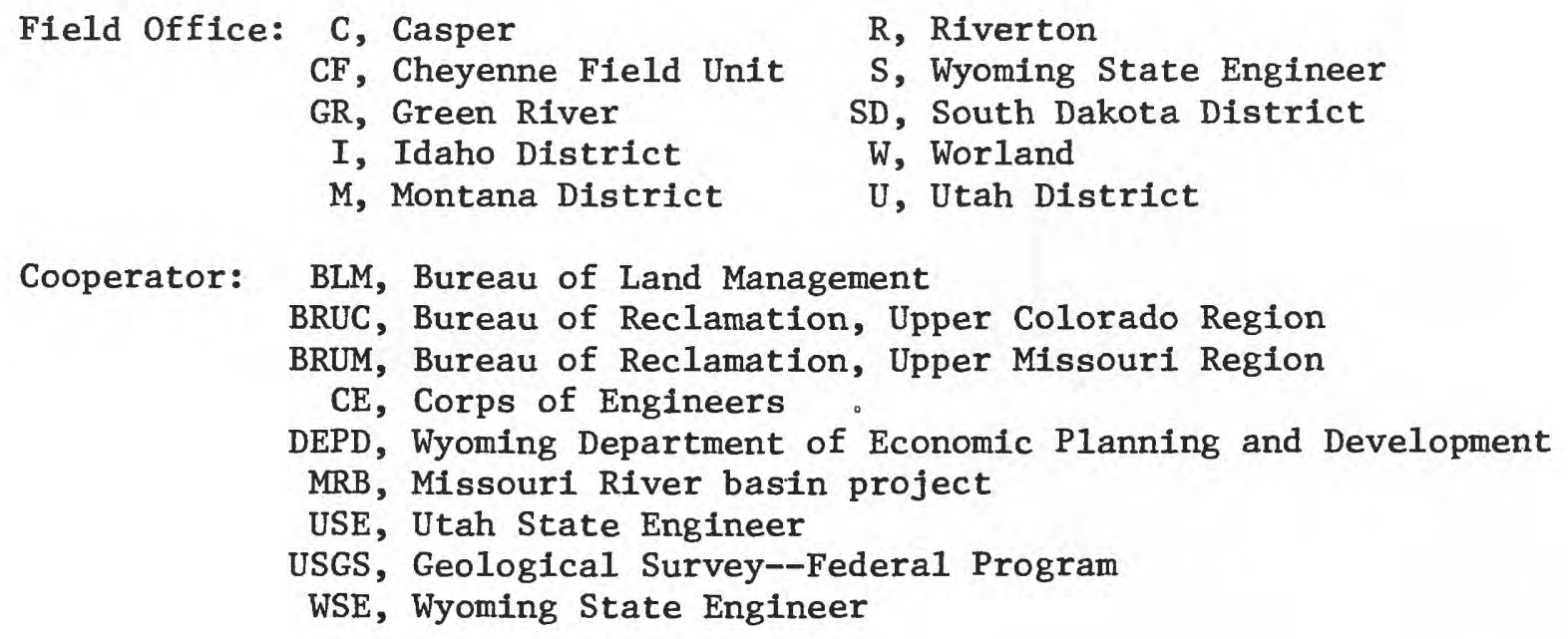




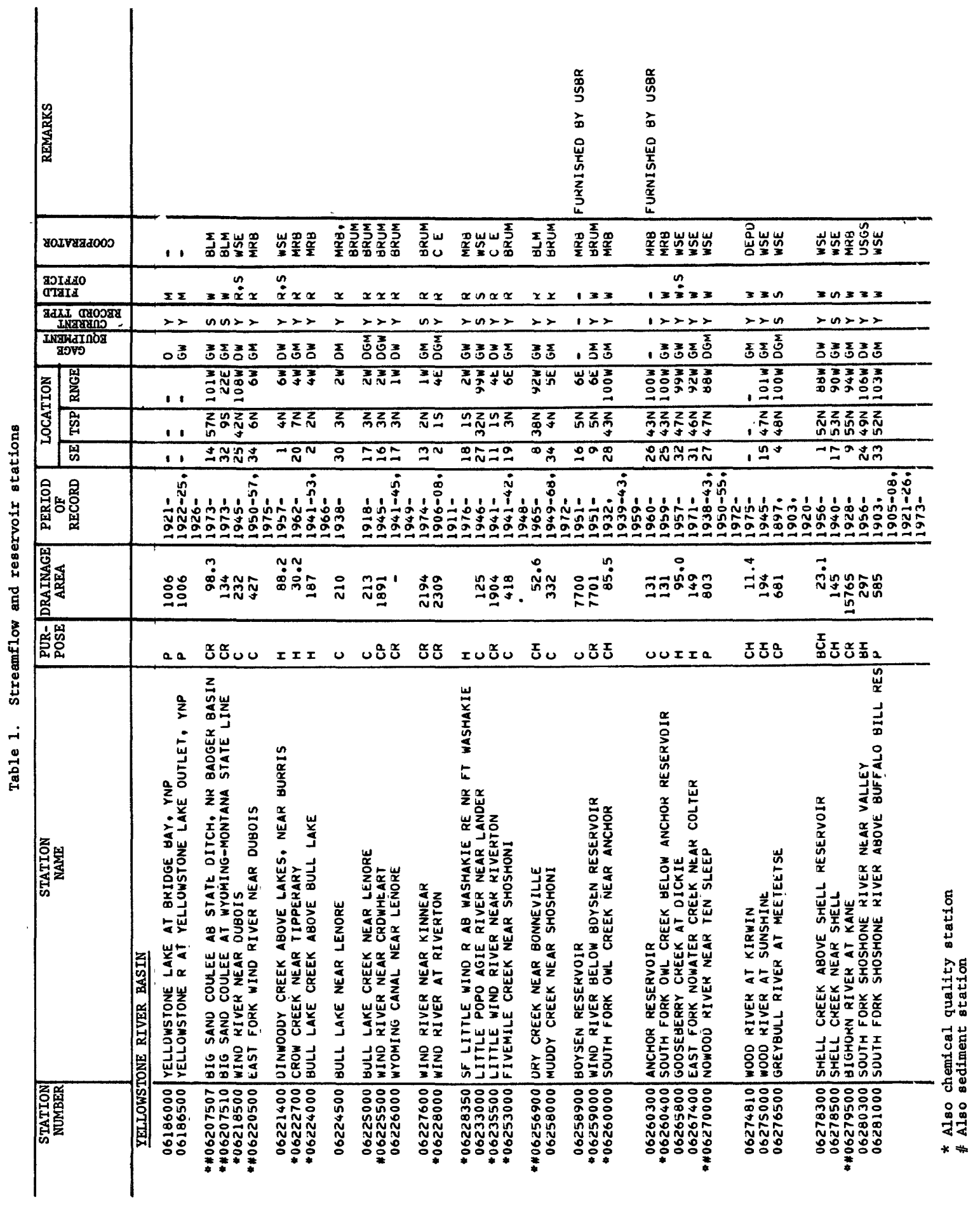




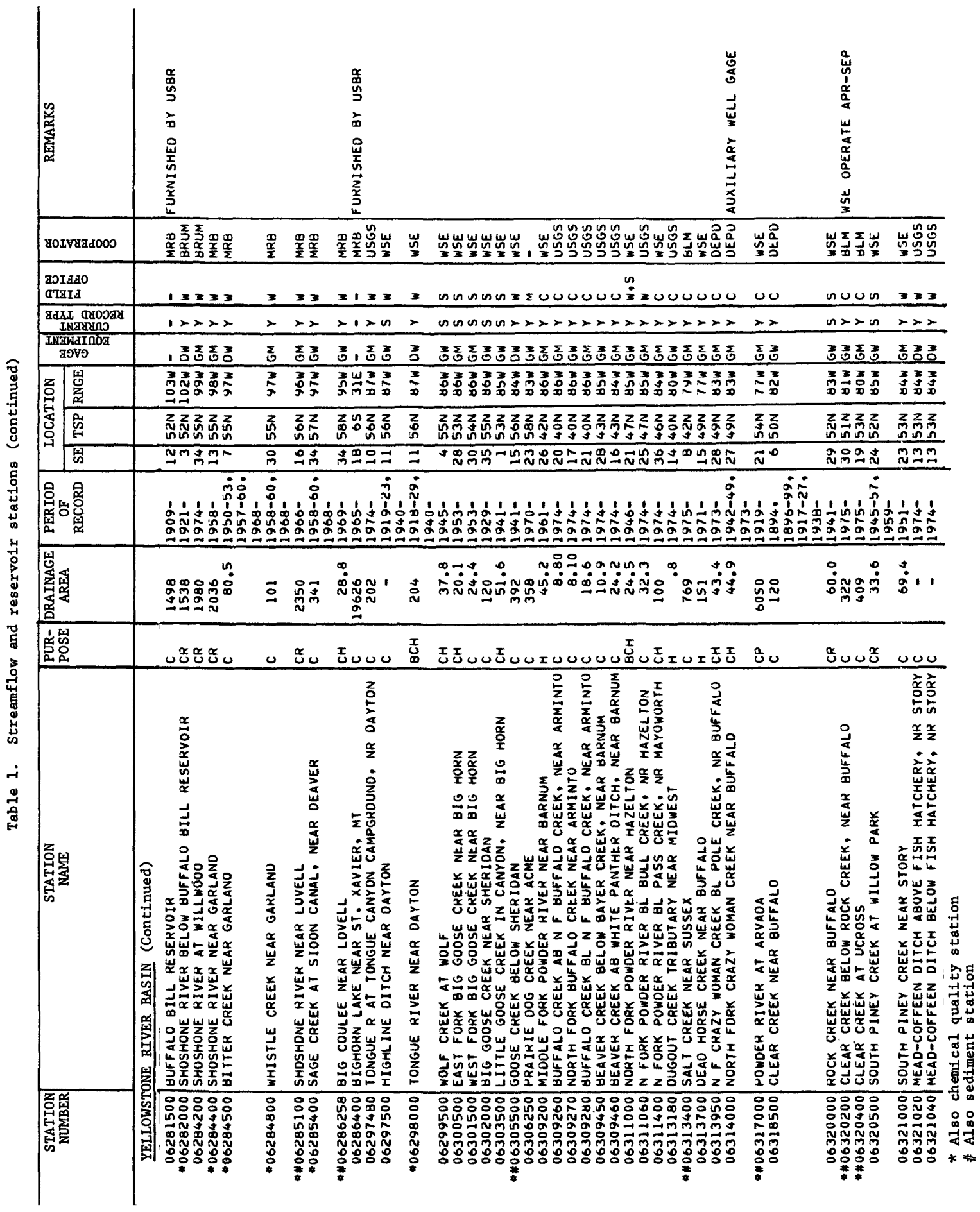




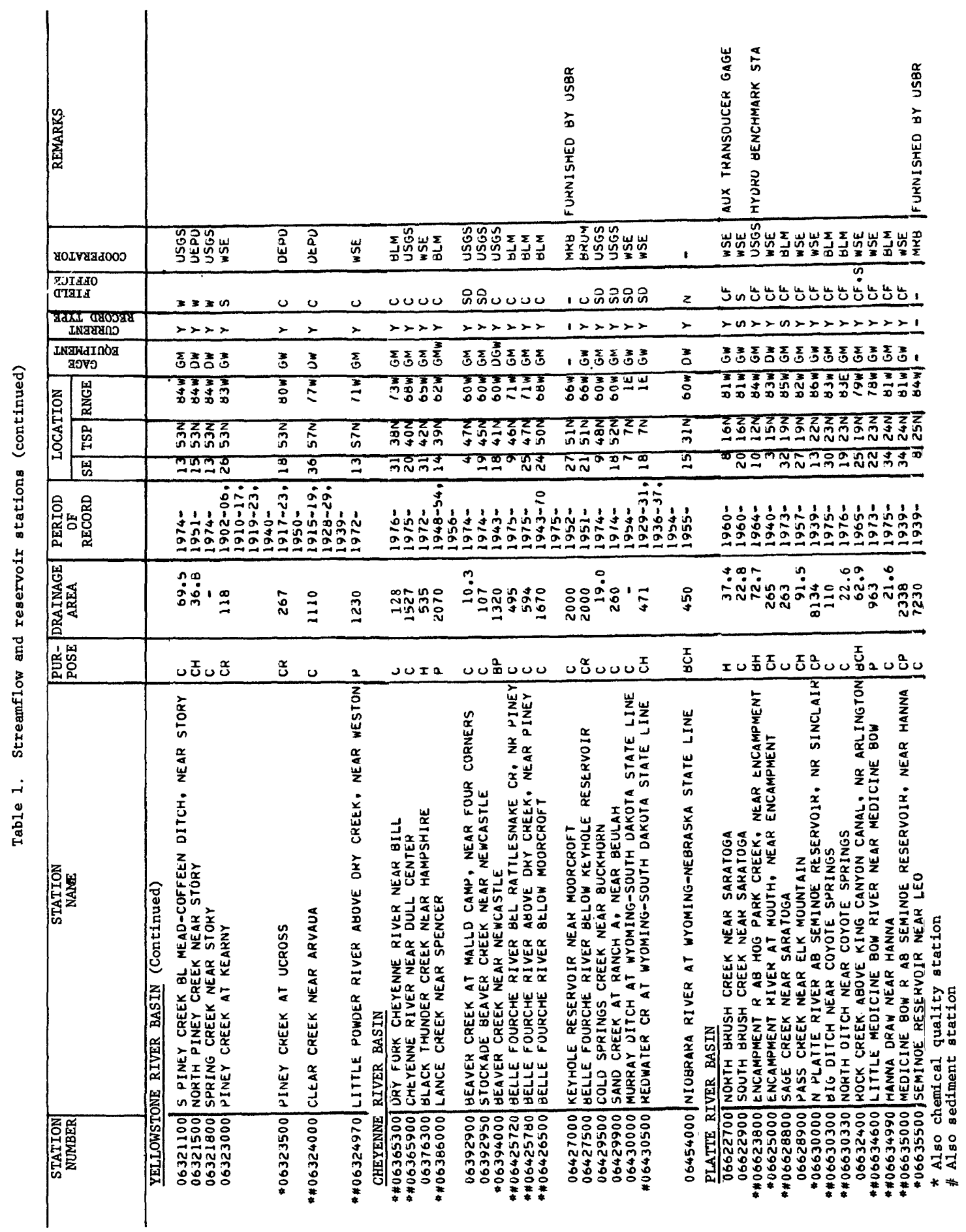




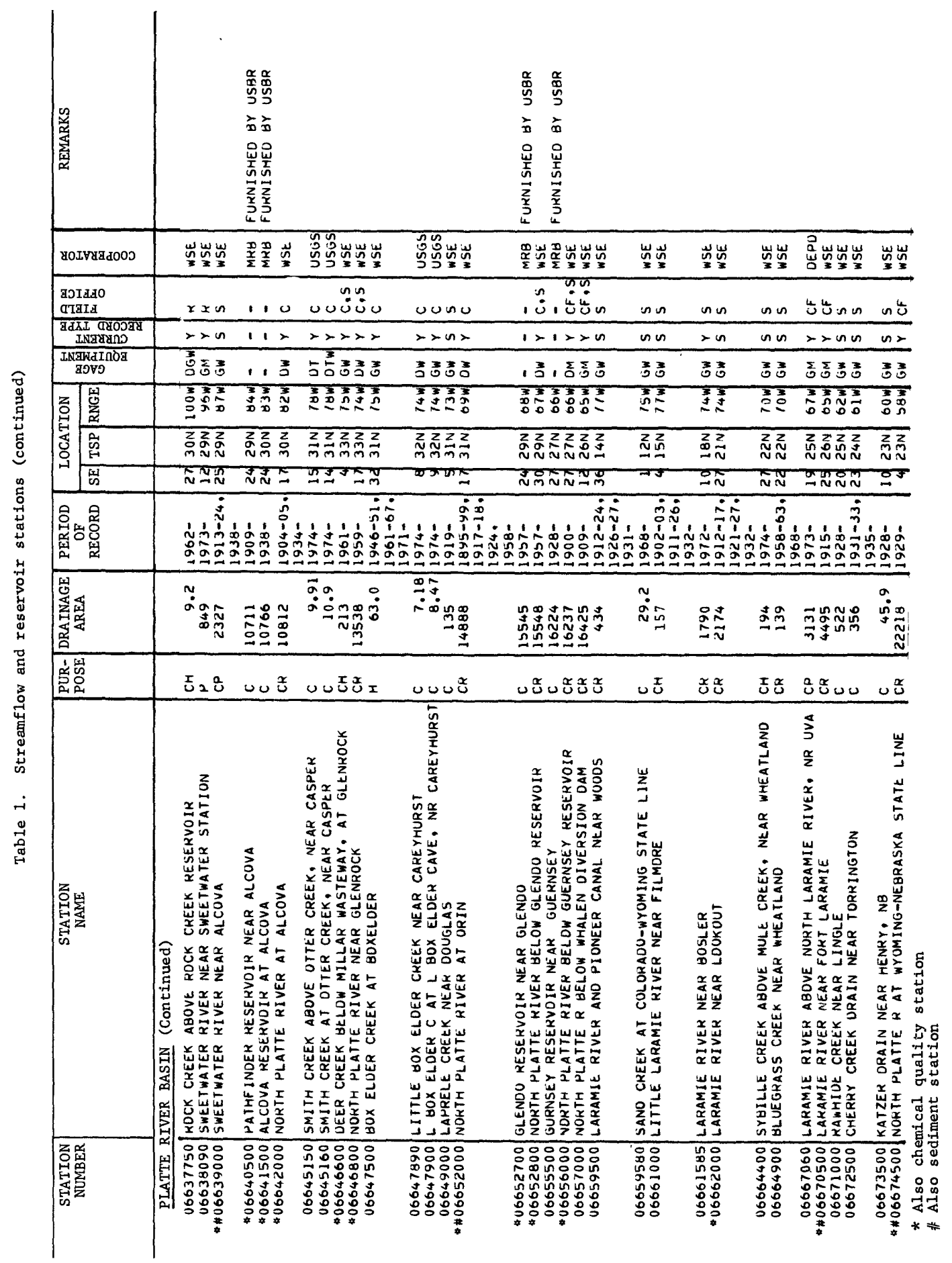




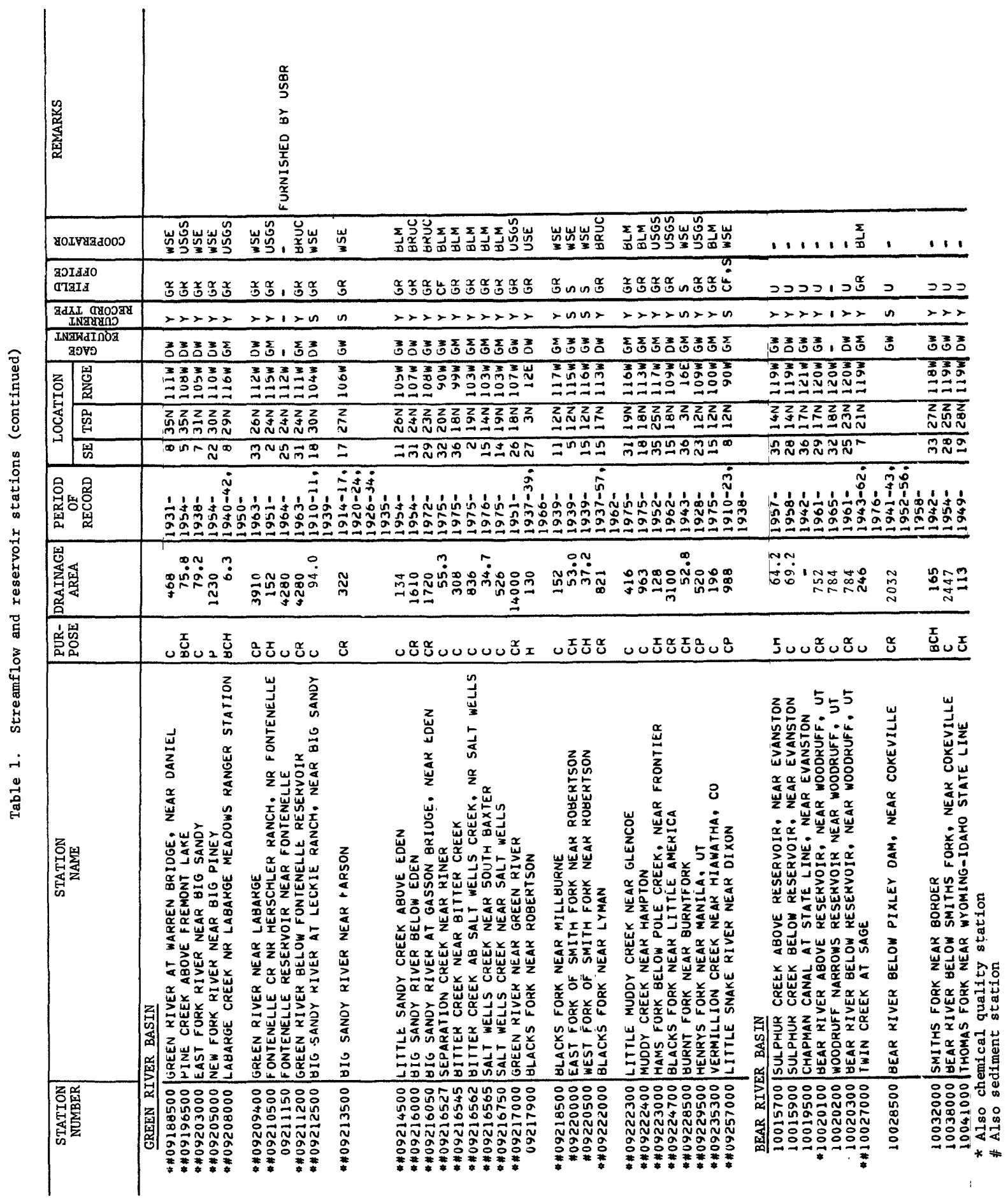




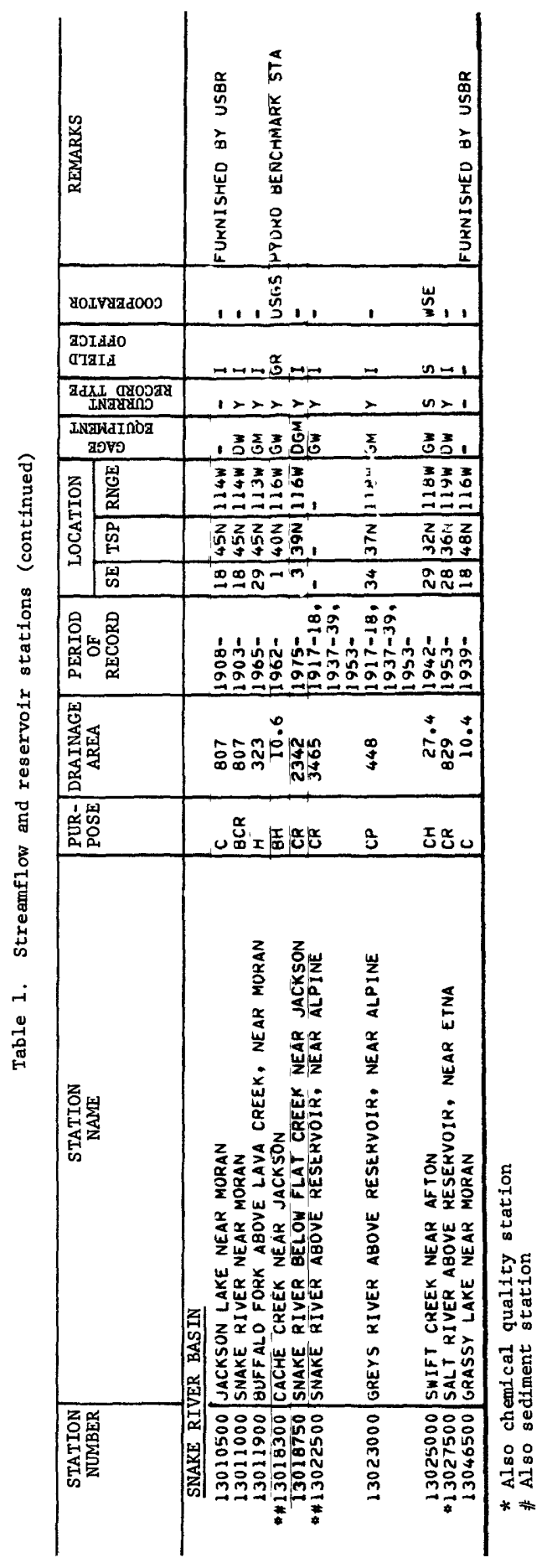


Explanation of abbreviations and codes used in table 2.

Period of Record: The dates given are the calendar years in which records began or ended. Breaks of less than a year are not shown.

Gage Equipment: CSI, crest-stage indicator

$S-R$, stage-rainfall recorder

Field Office: C, Casper

$\mathrm{CF}$, Cheyenne Field Unit

GR, Green River

$R$, Riverton

$\mathrm{W}$, Worland

Cooperator: BLM, Bureau of Land Management

WHD, Wyoming Highway Department 


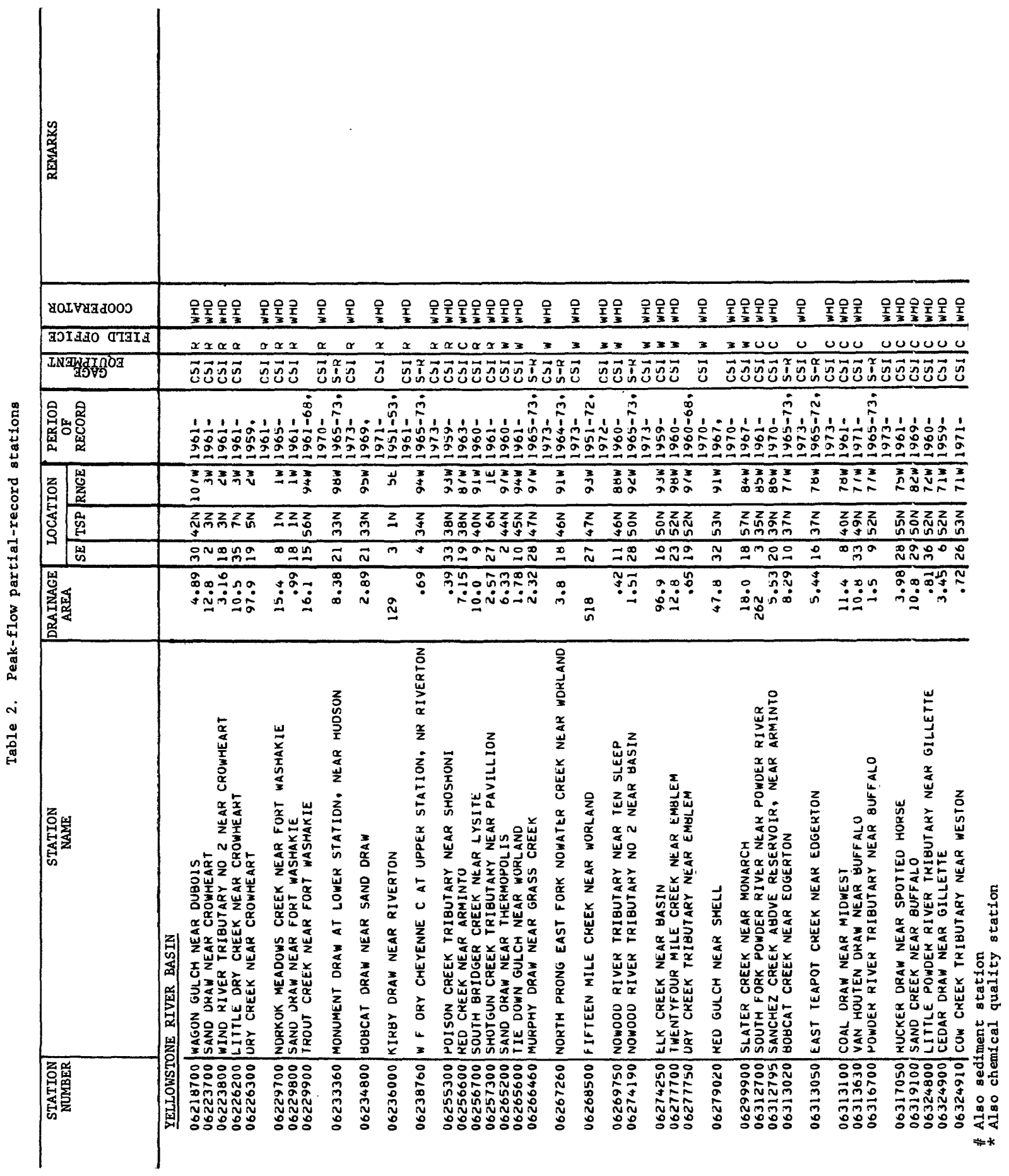




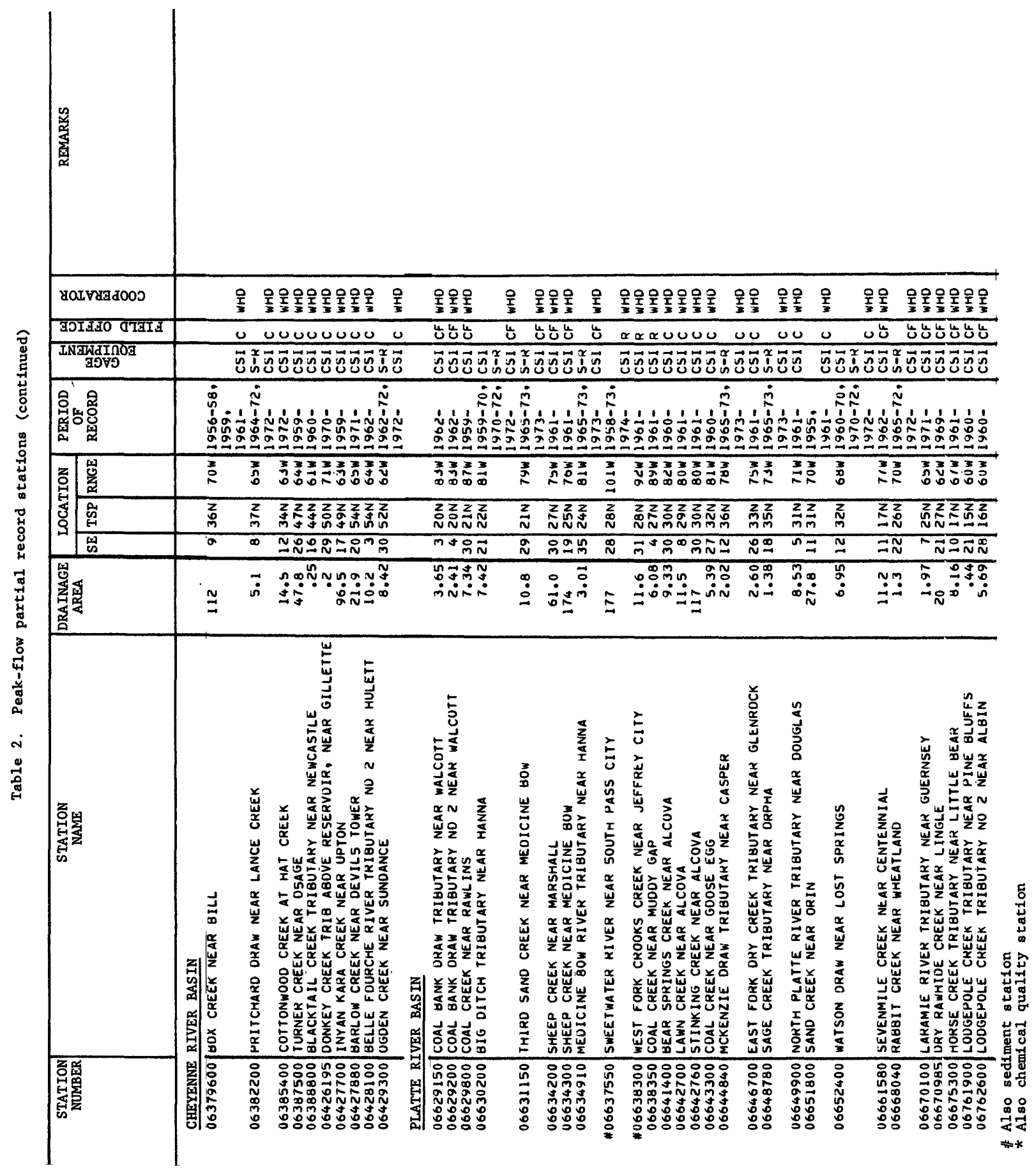




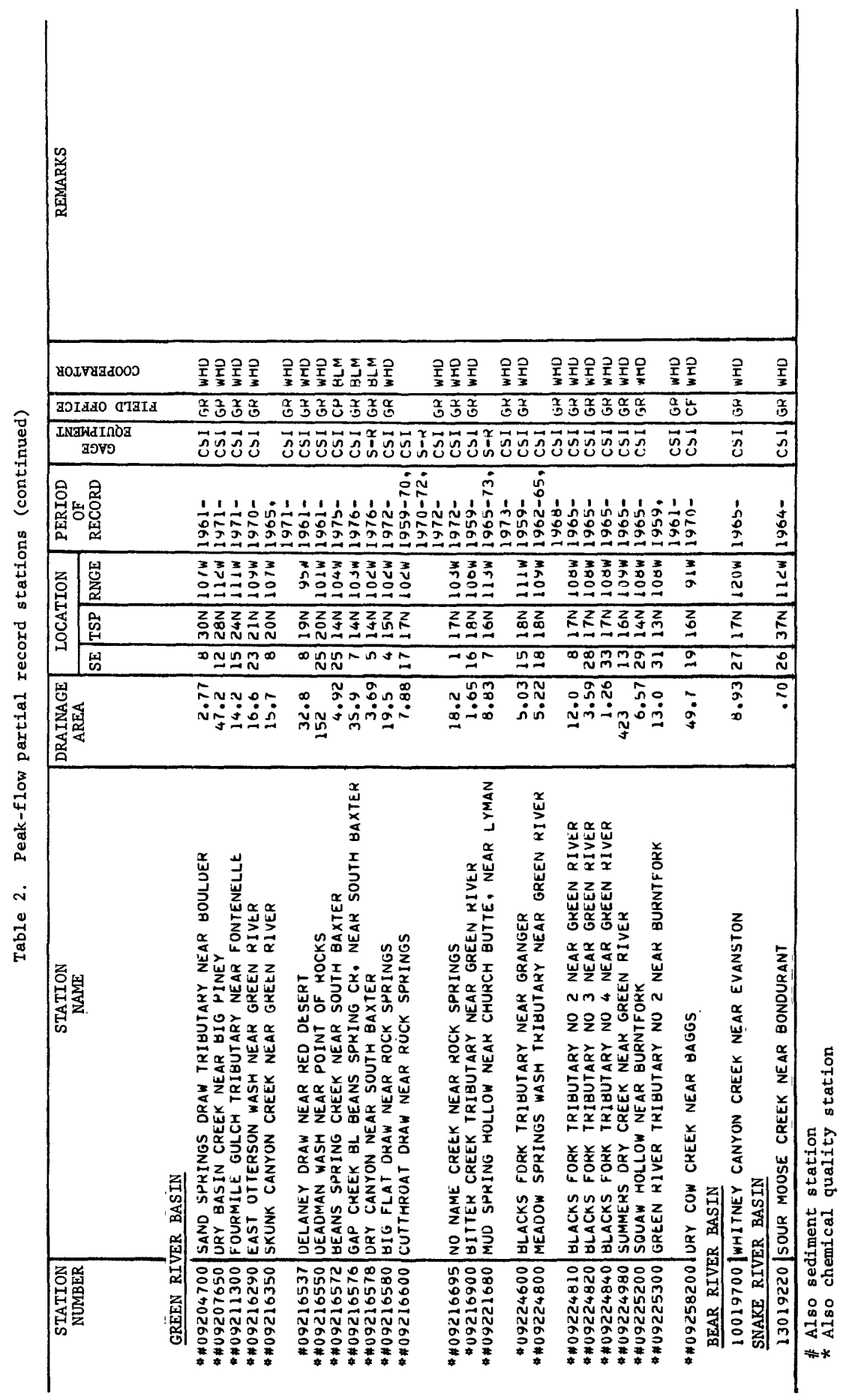


Explanation of abbreviations and codes used in table 3 .

Period of Record: The dates given are the calendar years in which records began or ended. Breaks of less than a year are rnt shown.

Cooperator: BLM, Bureau of Land Management

BRUC, Bureau of Reclamation, Upper Colorado Region

BRUM, Bureau of Reclamation, Upper Missouri Region

EPA, Environmental Protection Agency--Region 8

$M R B$, Missouri River basin project

USGS, Geological Survey--Federal Program

WDA, Wyoming Department of Agriculture

WDEQ, Wyoming Department of Environmental Quality

Sampling Frequency: C, continuous (recorder)

D, daily

BW, biweekly

BWM, biweekly and (or) monthly

$M$, monthly

MW, monthly, except weekly during irrigation season

$M Q$, monthly during summer, quarterly during winter

Q, quarterly

$\mathrm{HL}$, high and low flow samples only

$I$, infrequent or as requested

Analysis Schedule: 1, salinity (najor constituents)

2 , specific conductance

3, daily temperature (observed)

4, bacteria or chemical oxygen demand

5, field determinations of: $\mathrm{pH}$, specific conductance, dissolved oxygen, temperature, and (or) turbjdity

6, total coliform, fecal coliform, and (or) fecel streptococcus

7, nutrient

8 , trace metals

9, pesticides

10, radiochemical

11, biological

12, miscellaneous

Field Office: C, Casper

$\mathrm{CF}$, Cheyenne Field Unit

$\mathrm{CH}$, Cheyenne Hydrologic Surveillance Section

$\mathrm{CP}$, Cheyenne project personnel

GR, Green River

$R$, Riverton

$\mathrm{W}$, Worland 


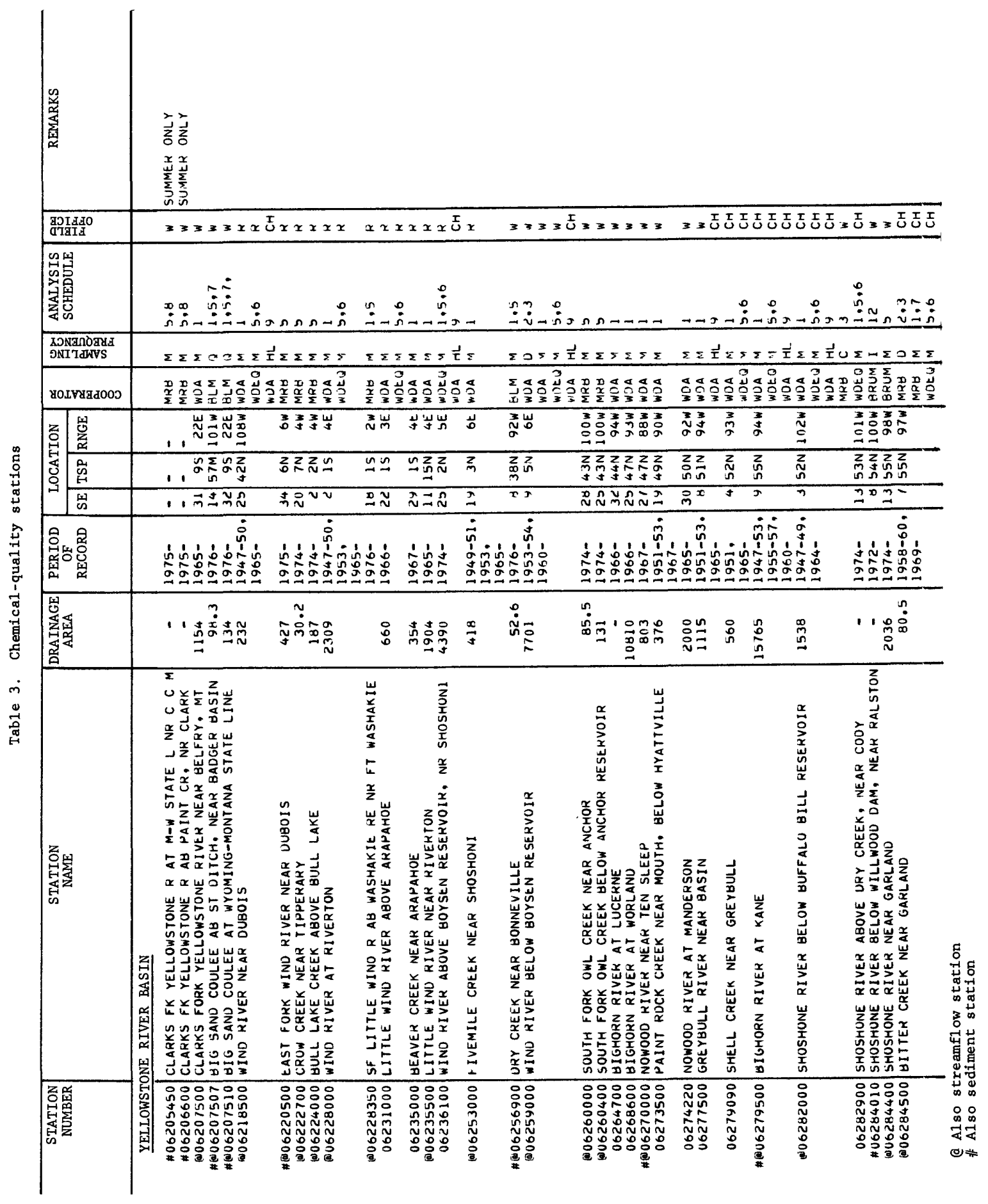




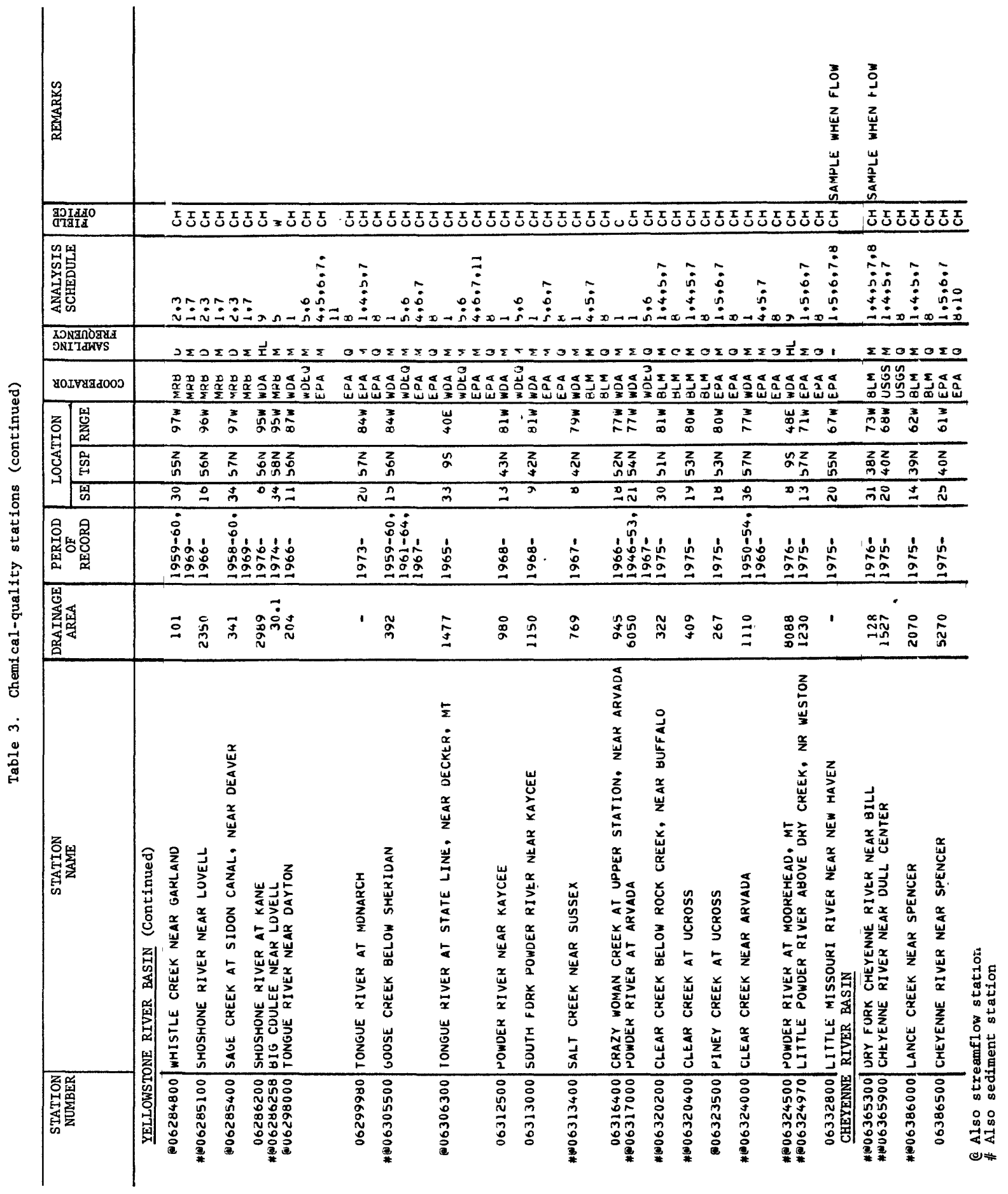




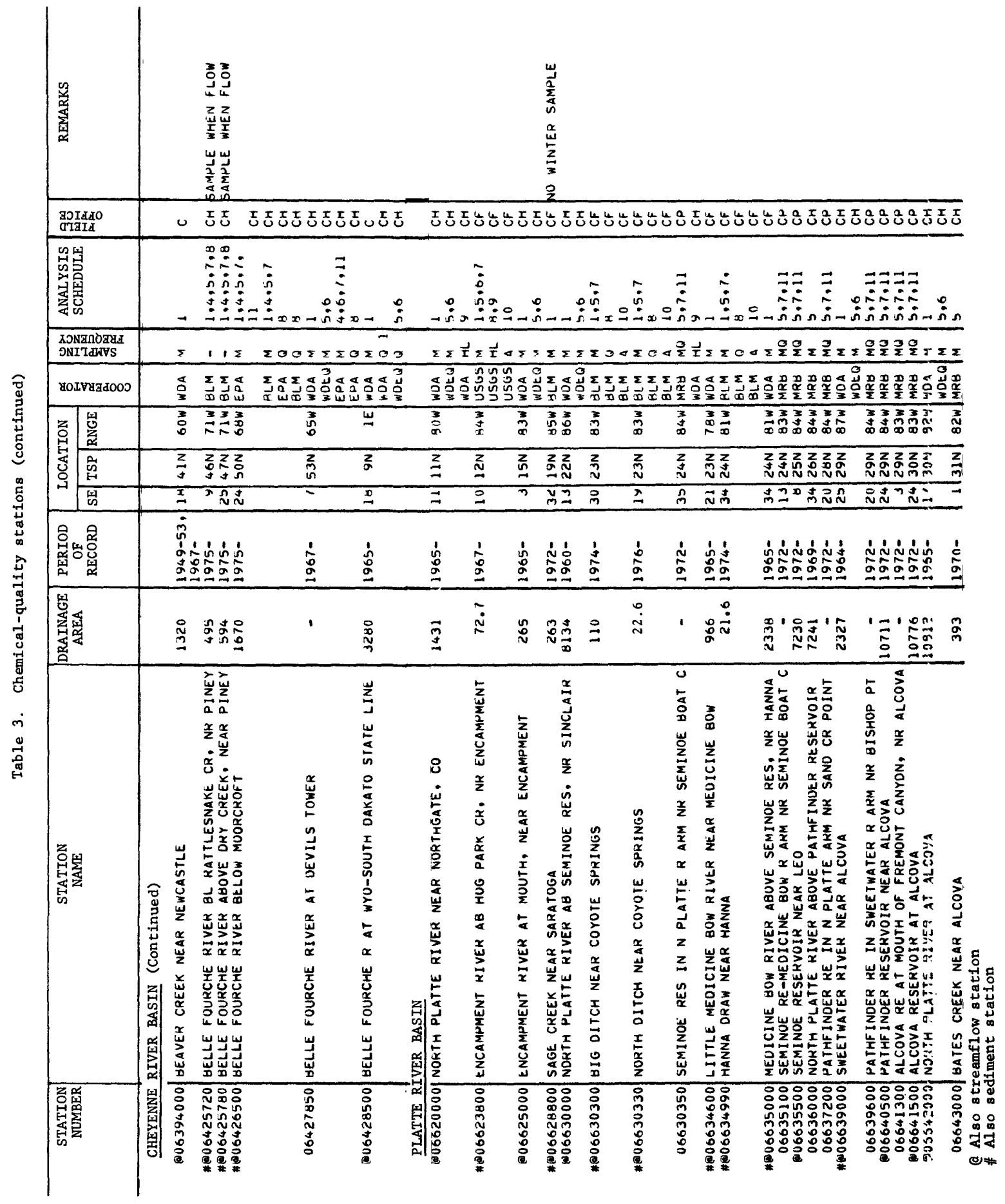




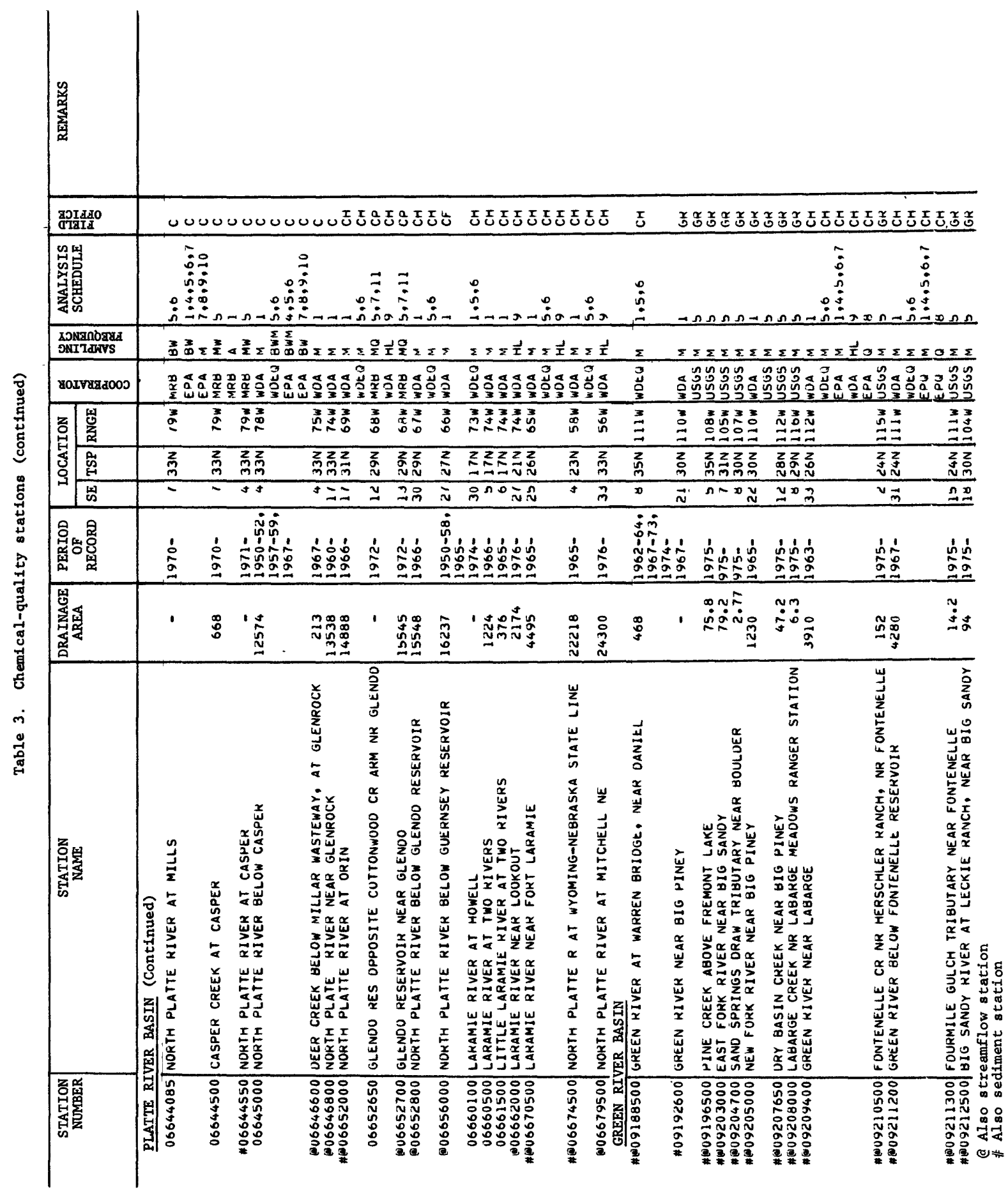




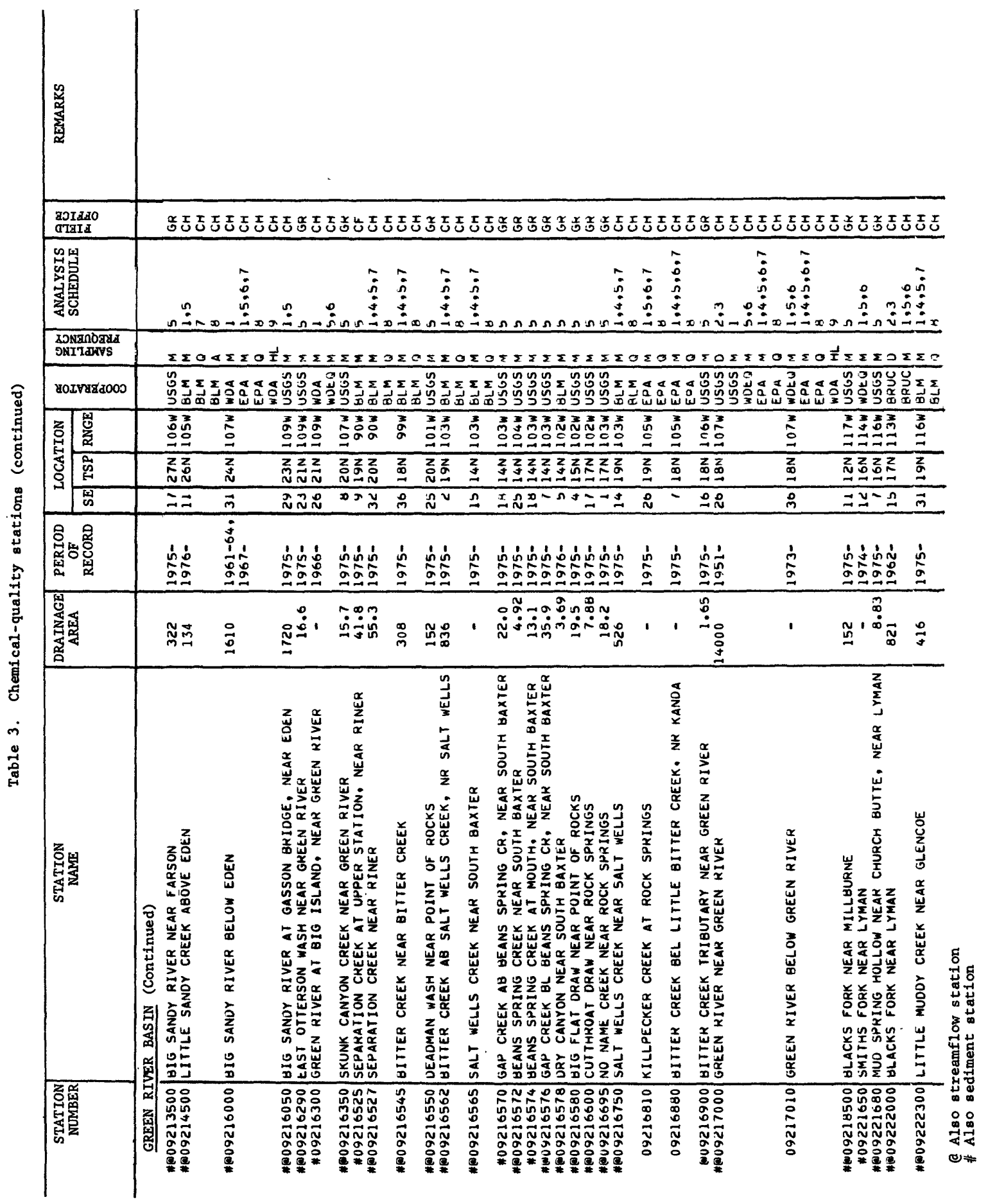




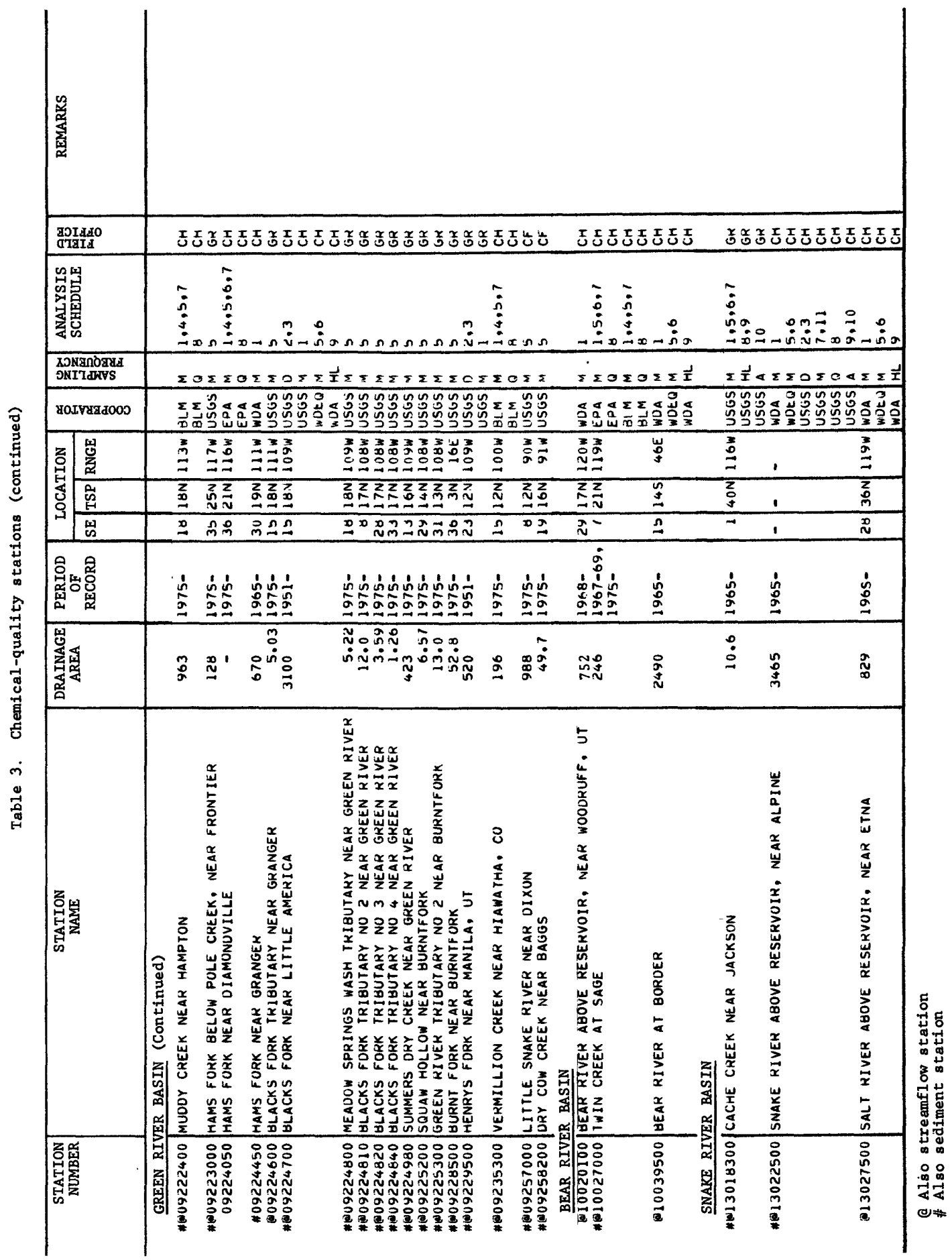


Explanation of abbreviations and codes used in table 4 .

Period of Record: The dates given are the calendar years in which records began or ended. Breaks of less than a year are not. shown.

Sampling Equipment: H, hydrographer sample

0 , observer sample

$P$, pumping sampler

$\mathrm{S}$, single-stage samplers

Suspended Sediment Sampling Frequency:

1, samples collected by observer once daily except during periods of rapidly changing flow when additional samples are collected.

2 , sampled by hydrographer at least once a month all year, with additional samples collected during periods of rapidly changing flow.

3, sampled by hydrographer at least once a month during open-water period and at least twice during extended periods of ice cover.

6 , samples collected as requested by cooperator.

7, pumping sampler serviced monthly or more often during periods of high runoff.

8, single-stage sampler serviced at least monthly. Samples collected by hydrographer if there is flow at time of visit.

9, infrequent sampling, sample when visiting station operated by WSE personnel.

Bed Material Sampling Frequency:

3, sample the surficial bed material in the cross section at least three times per year (high, medium, and low flow).

4, manual in-situ measurement and analysis of stream-bed material (pebble count), at a frequency of once per year (or longer), at the discretion of the District sediment specialist.

Laboratory: W, Worland

Cóoperator: BLM, Bureau of Land Management

BRUM, Bureau of Reclamation, Upper Missouri Region

MRB, Missouri River basin project

RIV, City of Riverton

USGS, Geological Survey--Federa1 Program

WSE, Wyoming State Engineer

Field Office: C, Casper

CF, Cheyenne Field Unit

$\mathrm{CH}$, Cheyenne Hydrologic Surveillance Section

GR, Green River

$\mathrm{R}$, Riverton

$\mathrm{W}$, Worland 


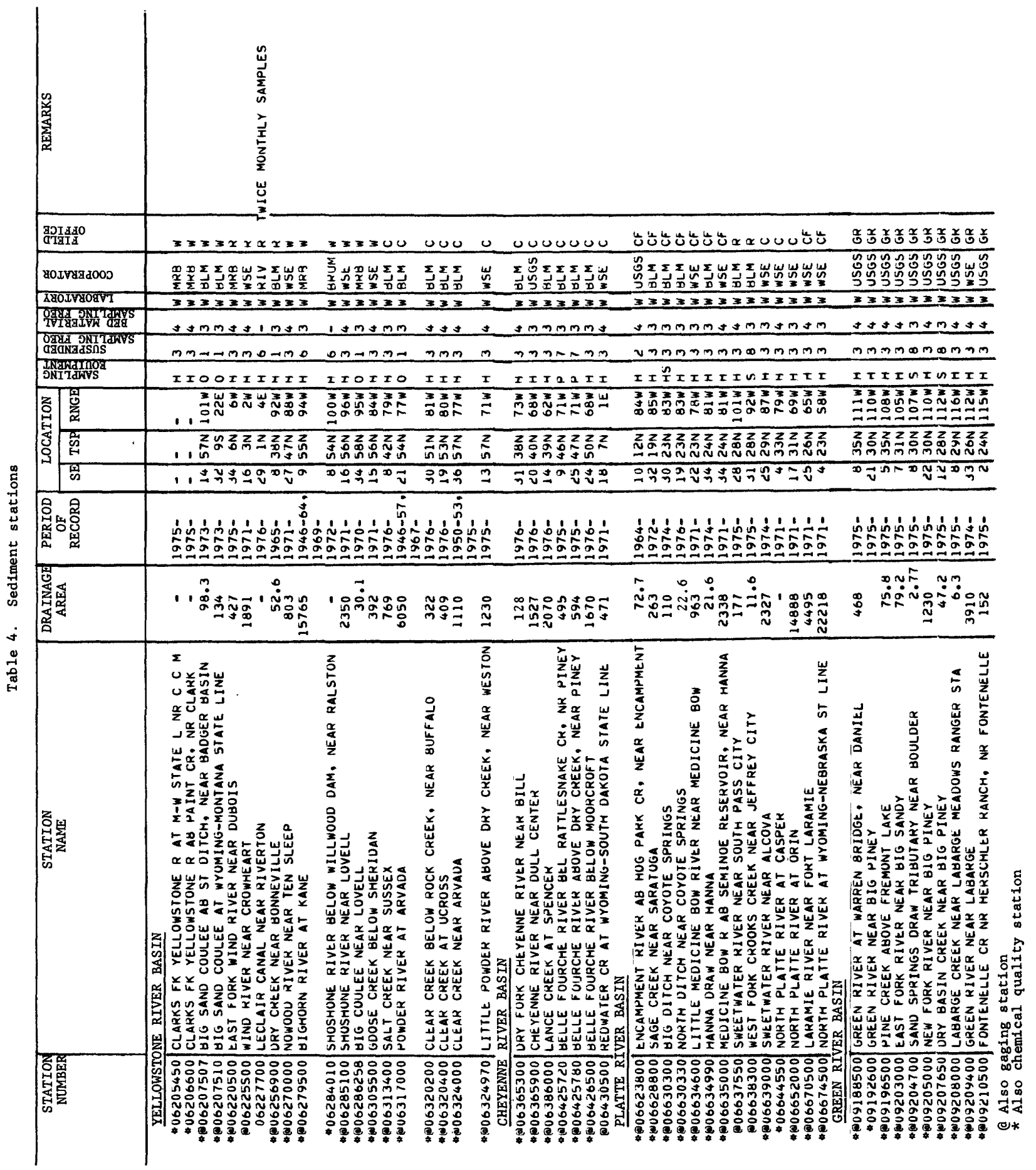




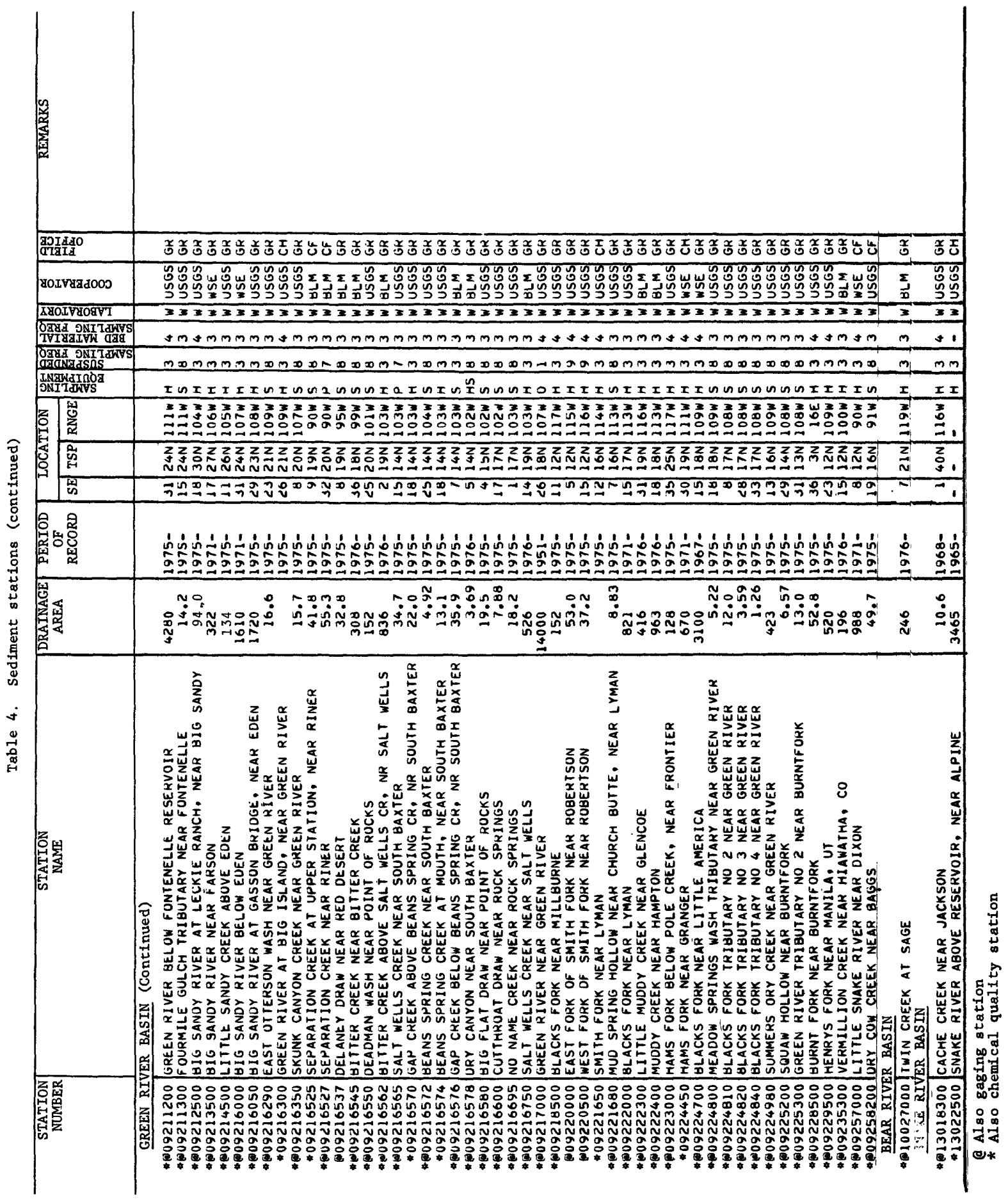




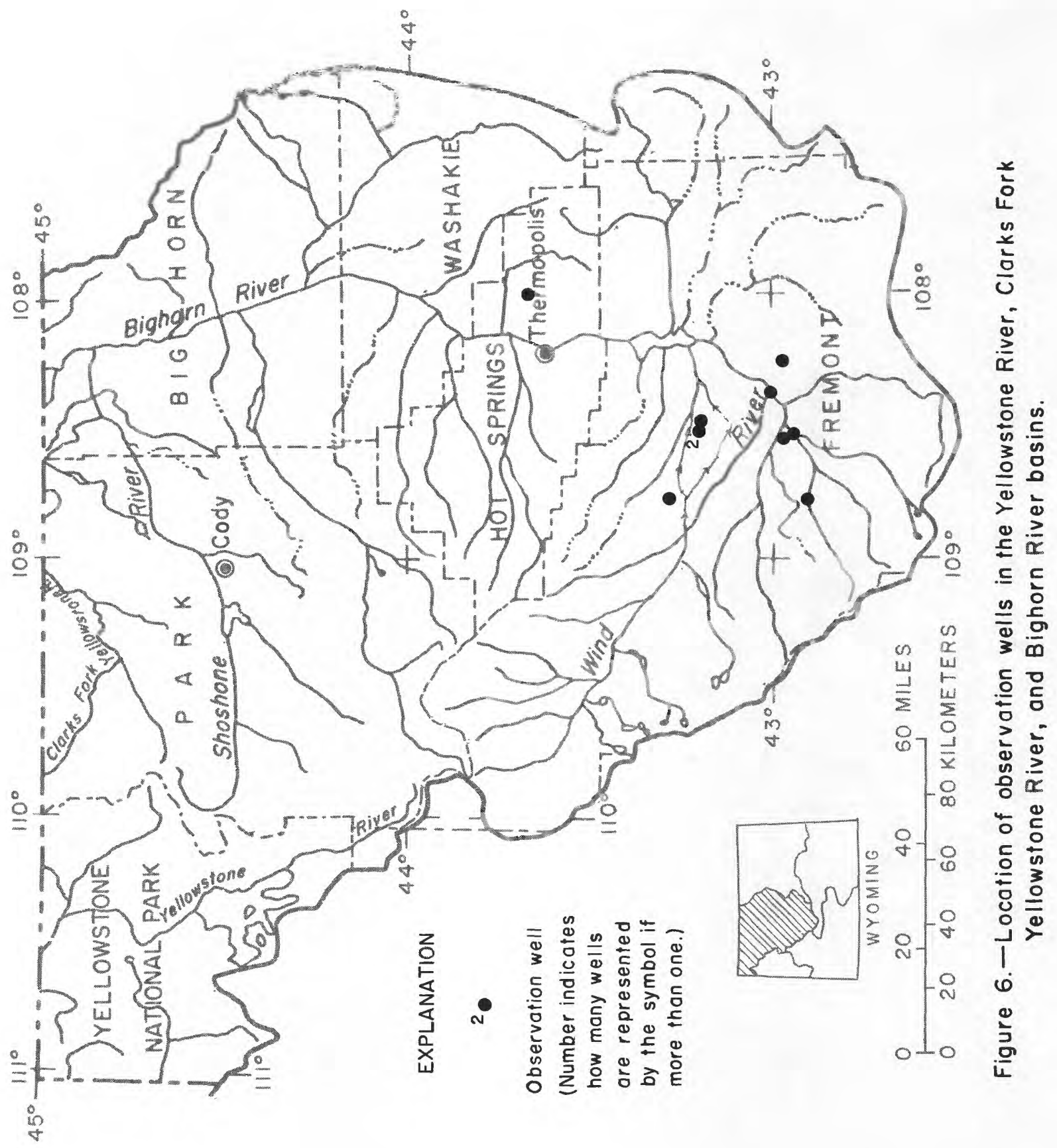




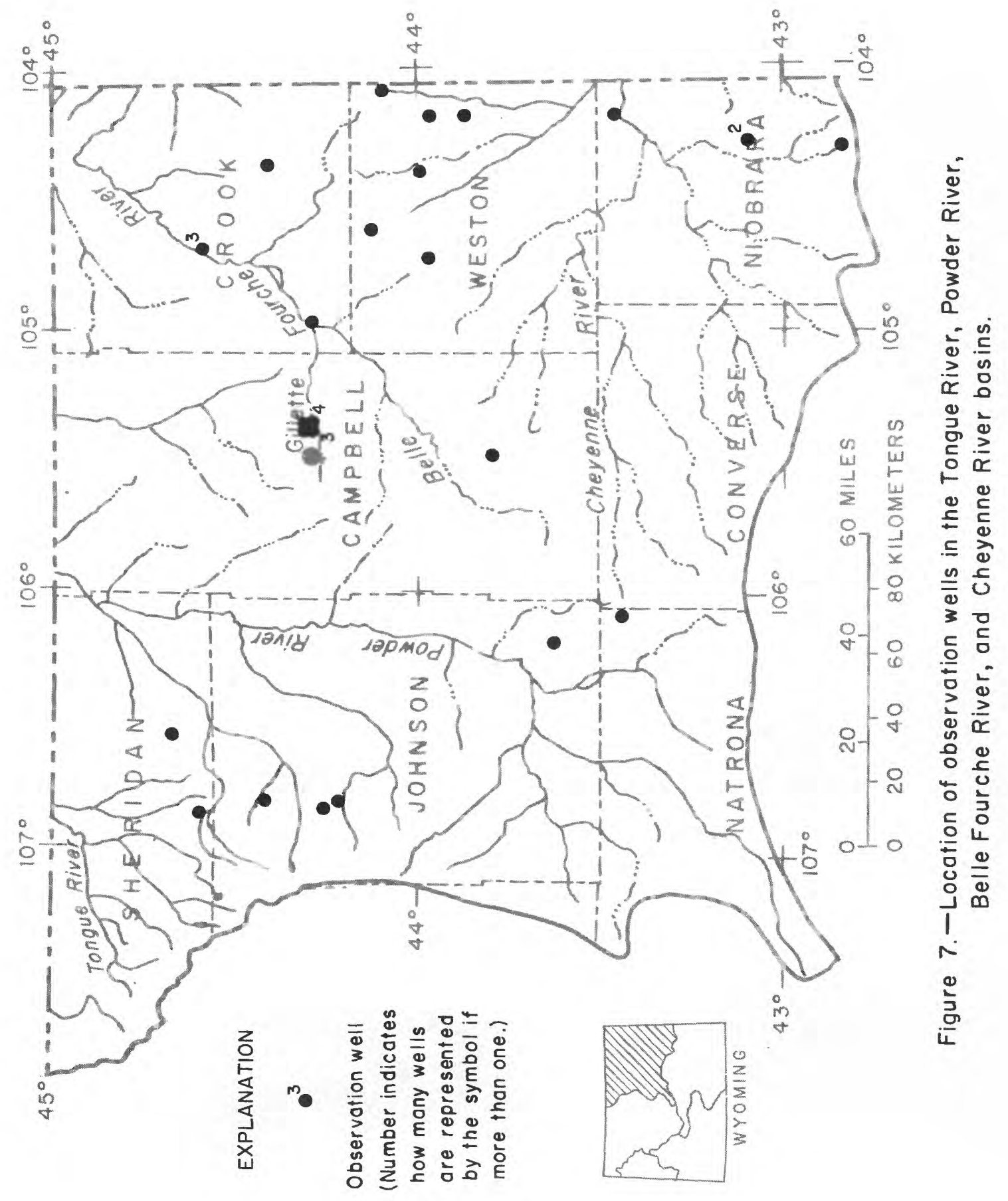




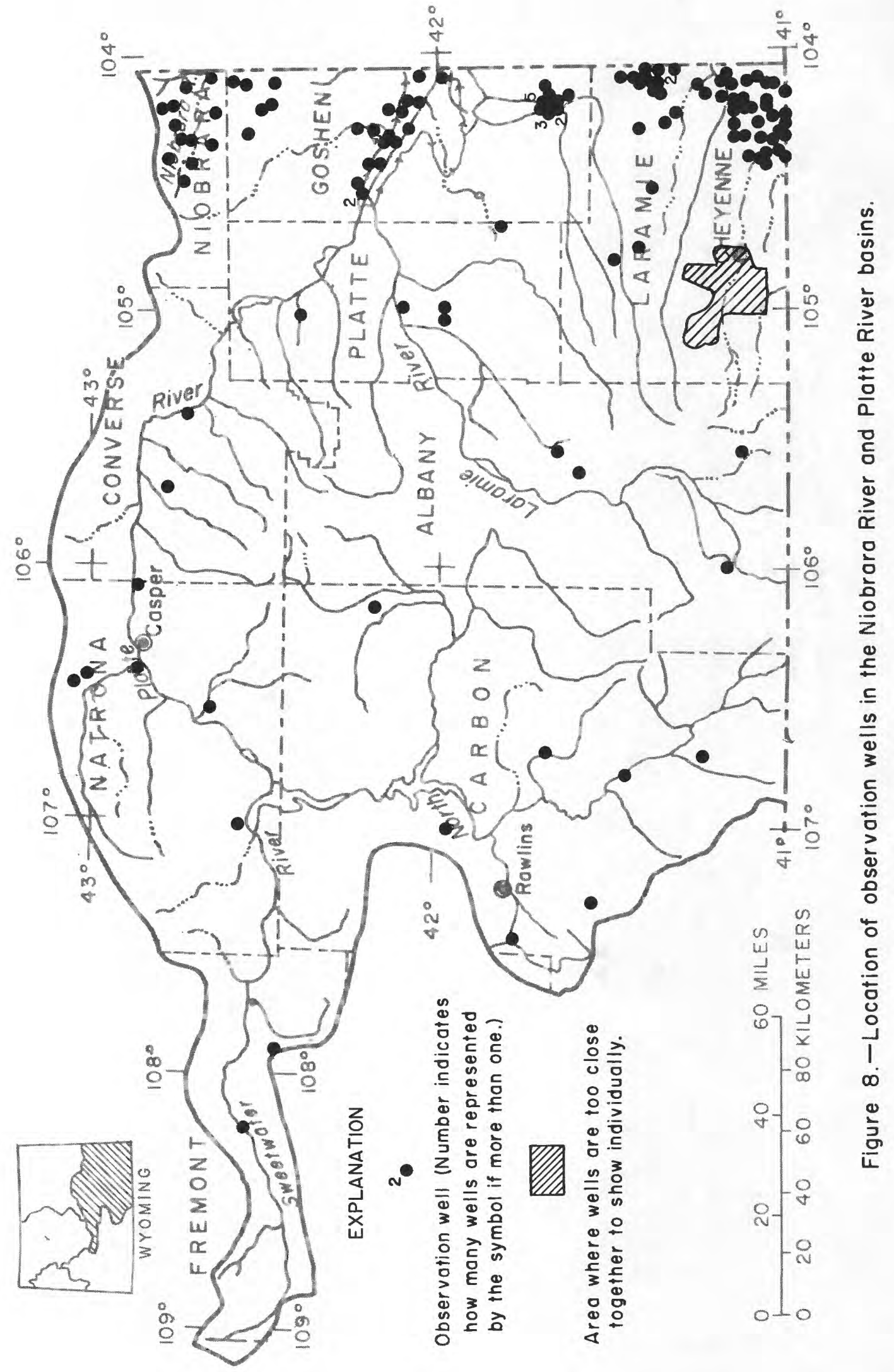




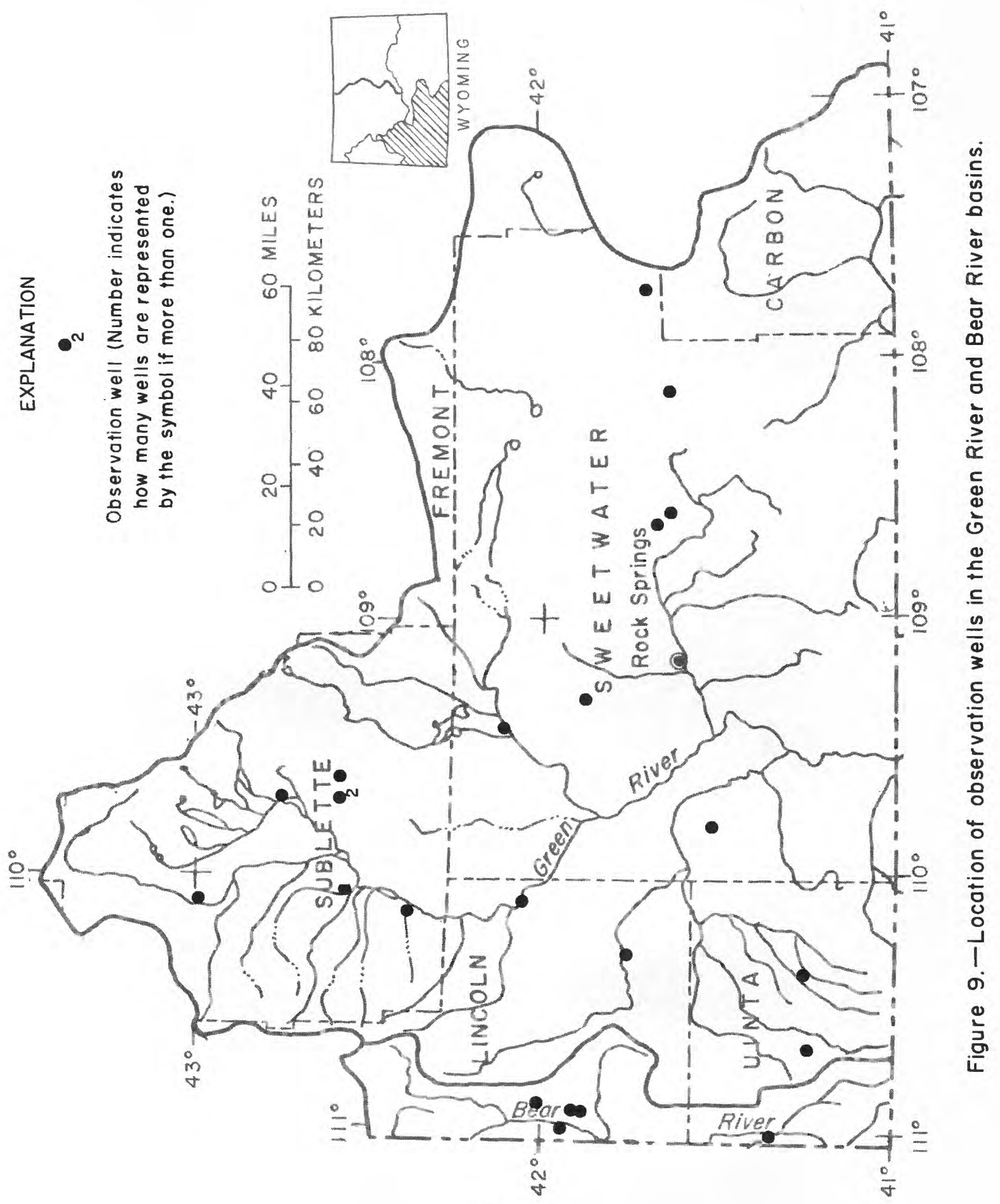


Explanation of abbreviations and codes used in table 5 .

Lat-Long-Seq No: The first six digits are the latitude in degrees, minutes, and seconds. The next seven digits are the longitude in degrees, minutes, and seconds. The last two digits indicate the sequence number of when the well was inventoried in the event more than one we11 has the same latitude and longitude.

Geologic Unit:

$\begin{array}{lll}111 & \text { ALVM } & \text { Alluvial deposits } \\ 111 & \text { TRRC } & \text { Terrace deposits } \\ 121 & \text { NRPK } & \text { North Park Formation } \\ 121 & \text { OGLL } & \text { Ogallala Formation } \\ 122 & \text { ARKR } & \text { Arikaree Formation } \\ 123 & \text { BRUL } & \text { Brule Formation } \\ 123 & \text { WRVR } & \text { White River Formation or Group } \\ 124 & \text { LNEY } & \text { Laney Shale Member of } \\ 124 & \text { WDRV } & \text { Wind River Formation } \\ 124 & \text { WSTC } & \text { Wasatch Formation } \\ 125 & \text { FRUN } & \text { Fort Union Formation } \\ 211 & \text { ALMD } & \text { Almond Formation } \\ 211 & \text { FXHL } & \text { Fox Hills Sandstone }\end{array}$

$\begin{array}{ll}211 & \text { LNCE } \\ 211 & \text { MVRD } \\ 211 & \text { STEL } \\ 217 & \text { CLVL } \\ 217 & \text { LKOT } \\ 221 & \text { SNDC } \\ 237 & \text { SPRF } \\ 317 & \text { CSPR } \\ 317 & \text { FRLL } \\ 317 & \text { MNKT } \\ 331 & \text { MDSN } \\ 337 & \text { PHSP } \\ 374 & \text { FLTD } \\ 374 & \text { GRVR }\end{array}$

Lance Formation

Mesaverde Formation

Steele Shale

Cloverly Formation

Lakota Formation

Sundance Formation

Spearfish Formation

Casper Formation

Forelle Limestone

Minnekahta Limestone

Madison Formation or Group

Pahasapa Limestone

Flathead Quartzite or Sandstone

Gros Ventre Formation

The 7-character geologic unit code given above consists of two parts. The first three characters are numeric and identify the Era, System, and Series of the rock unit. The next four characters are in alpha mnemonic code for the name of the rock-stratigraphic unit.

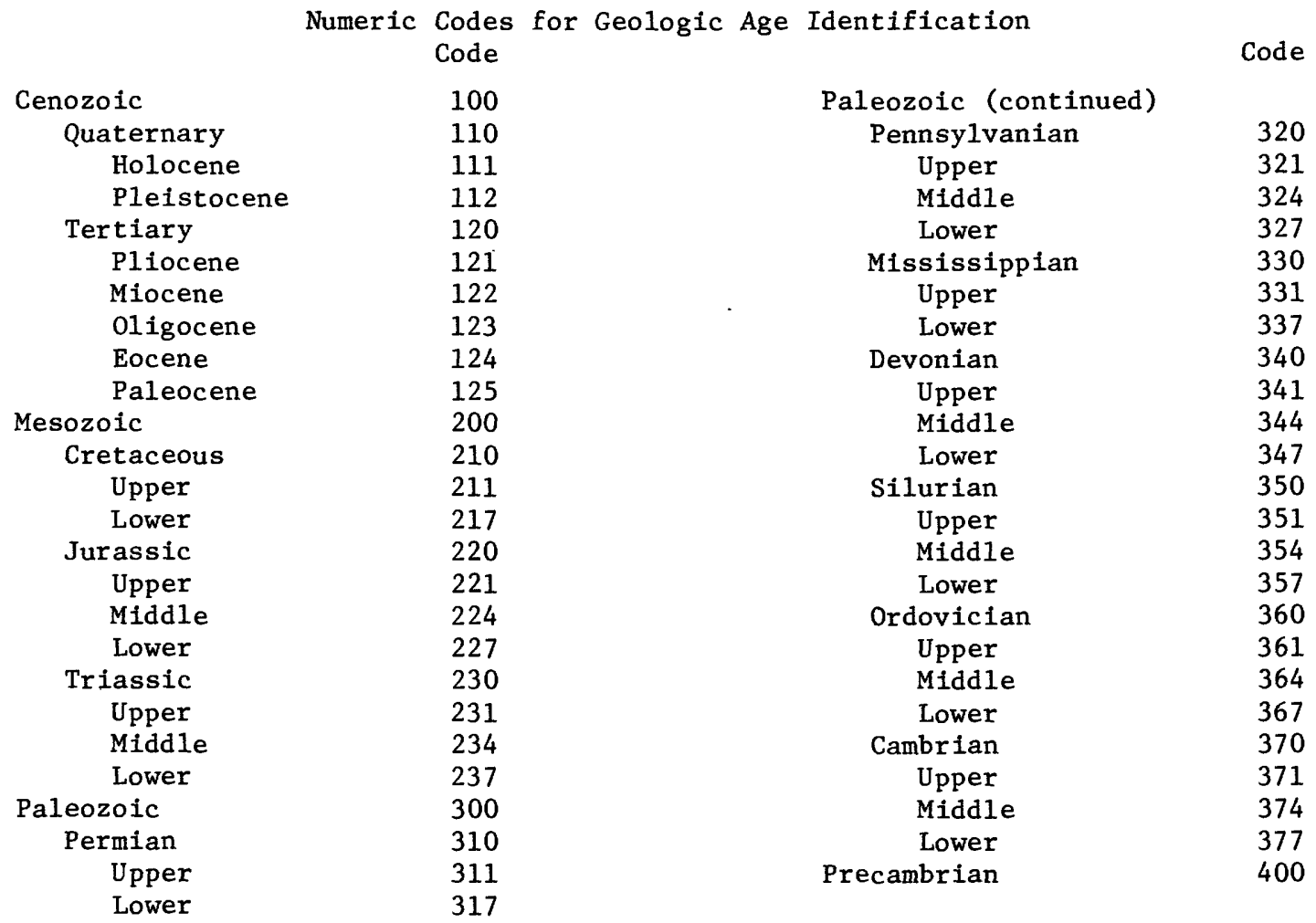


Explanation of abbreviations and codes used in table 5 (continued).

Cooperator: CHEY, City of Cheyenne

USGS, Geological Survey--Federal Program

WSE, Wyoming State Engineer

Field Office: C, Casper

$\mathrm{CF}$, Cheyenne Field Unit

$\mathrm{CH}$, Cheyenne Hydrologic Surveillance Section

GR, Green River

$R$, Riverton

$\mathrm{SD}$, South Dakota District

$\mathrm{W}$, Worland

Frequency of Observation:

$C$, continuous (graphic or digital recorder)

$M$, monthly (12 visits per year)

$\mathrm{BM}$, bimonth1y (6 visits per year)

$Q$, quarterly ( 4 visits per year)

$\mathrm{SA}$, semiannual (2 visits per year)

A, annual (1 visit per year)

$I$, infrequent or as required

Period of Record: The dates given are the calendar years in which records began or ended. A record consists of one or more measurements during a calendar year. 


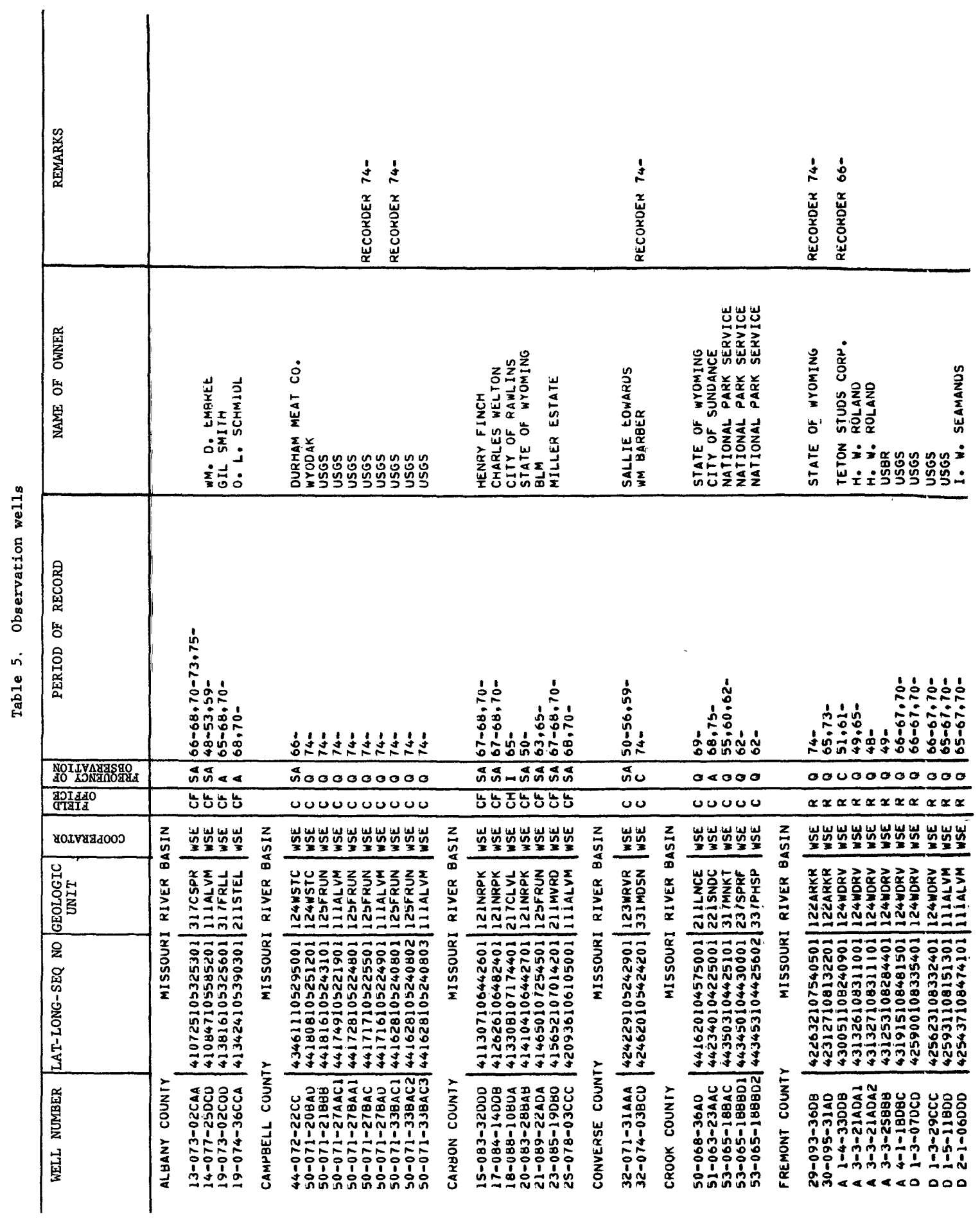




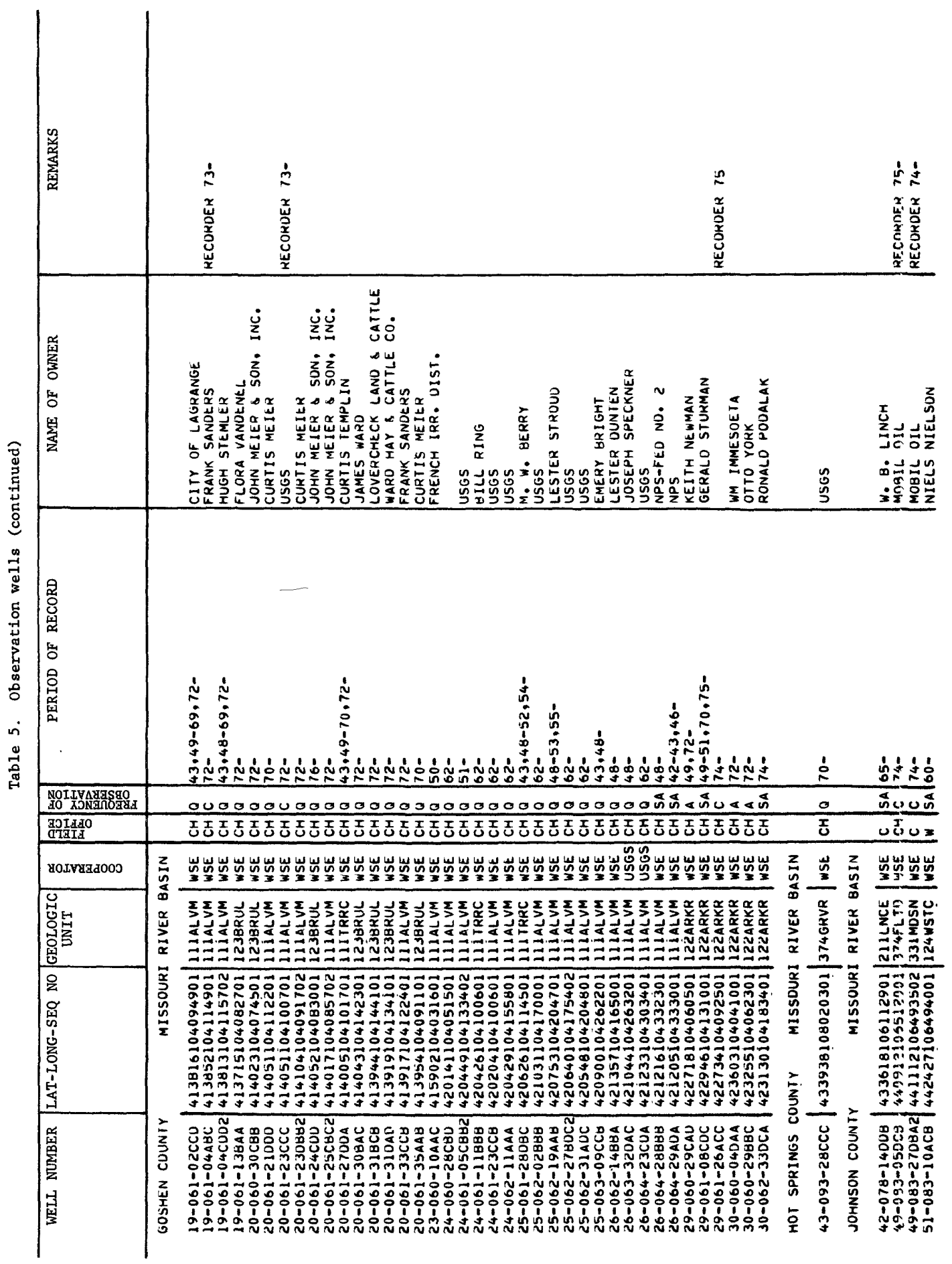




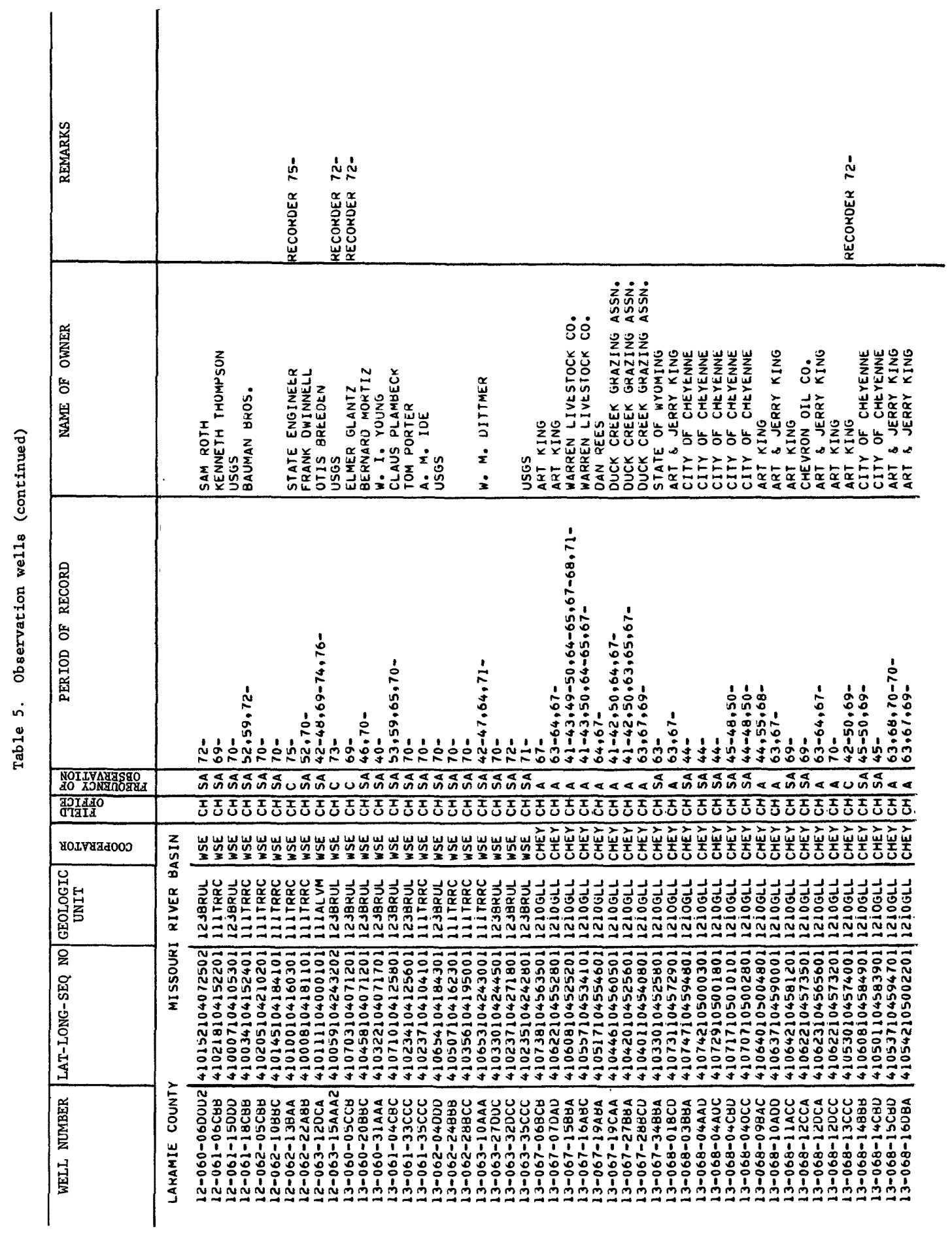




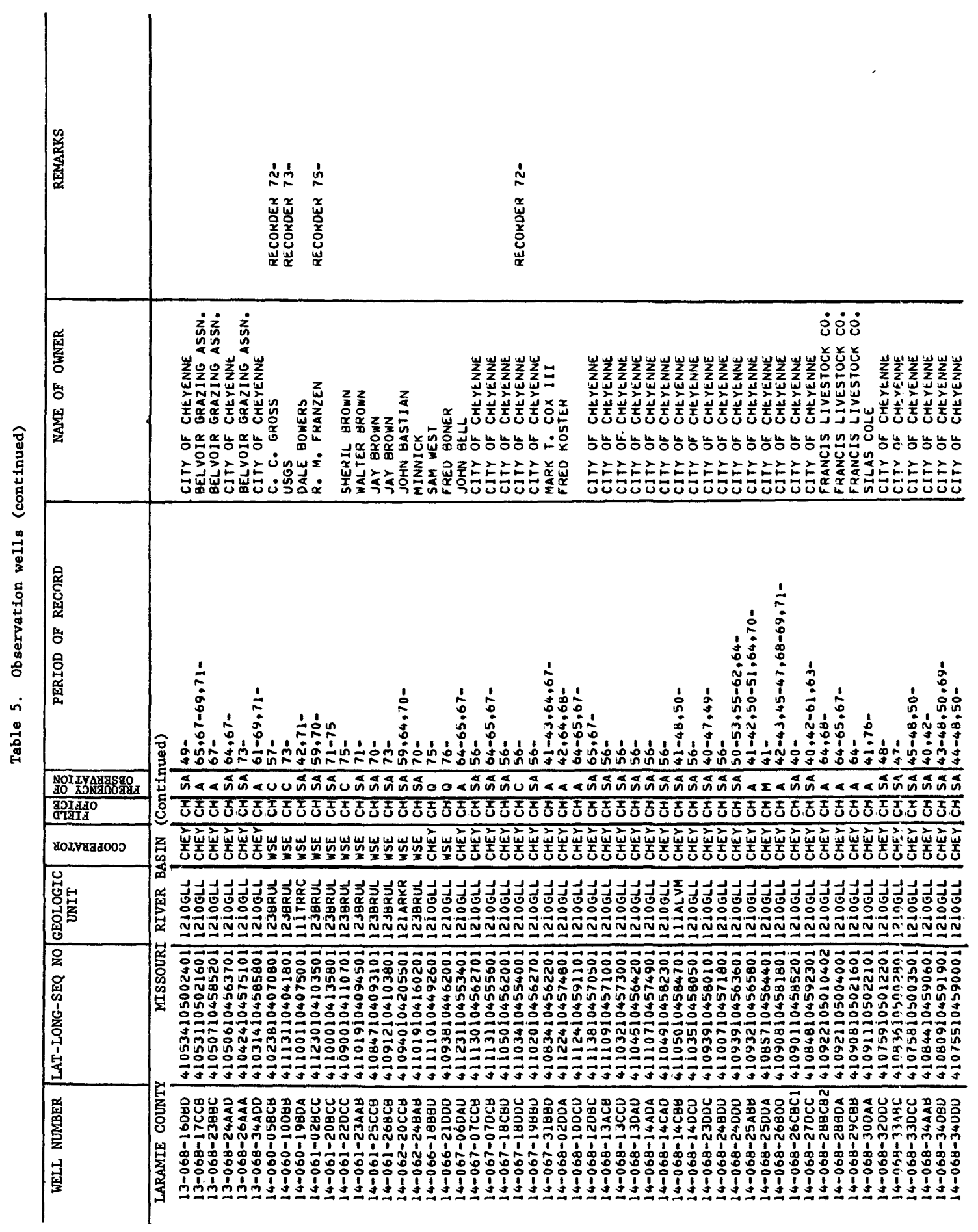




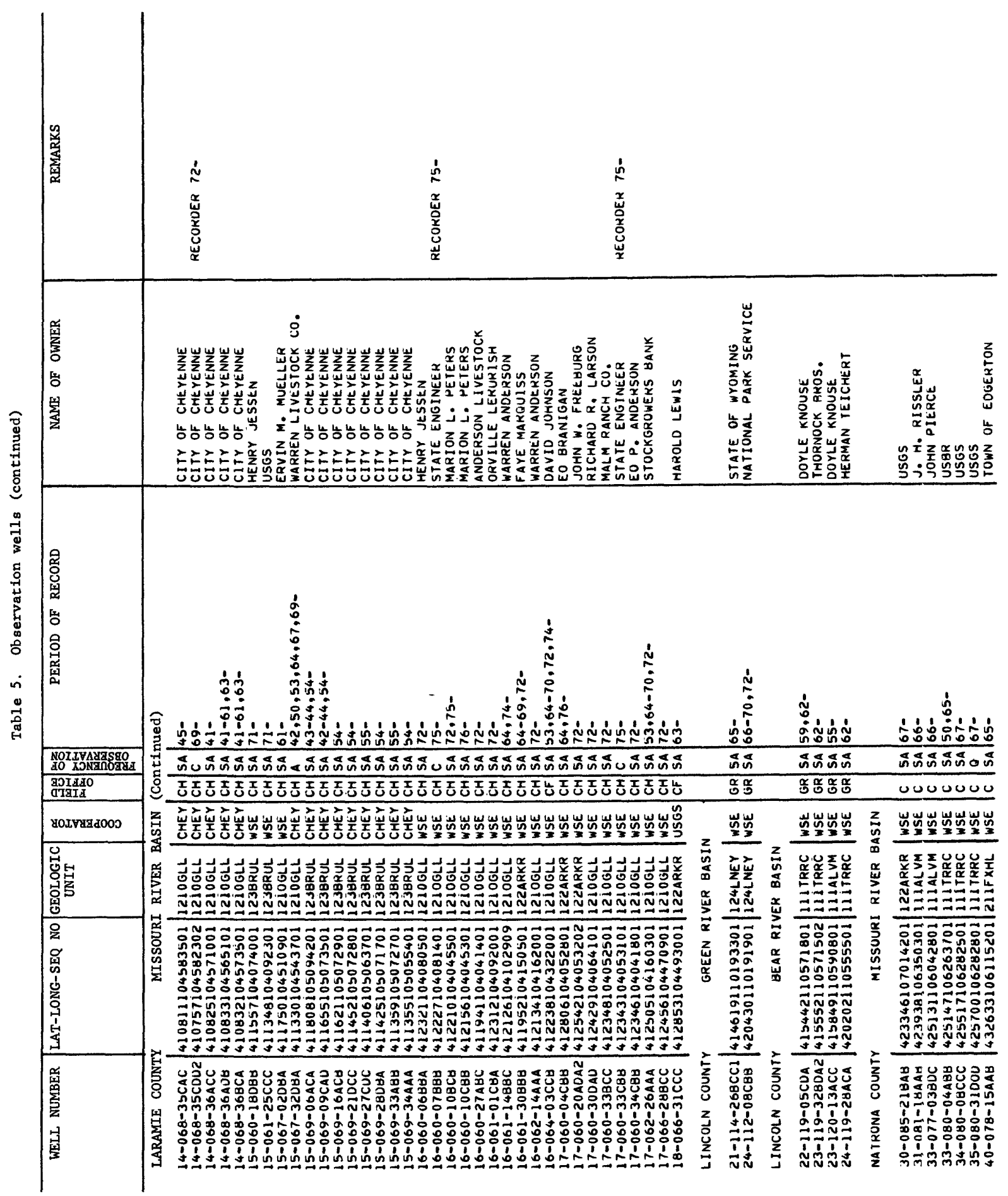




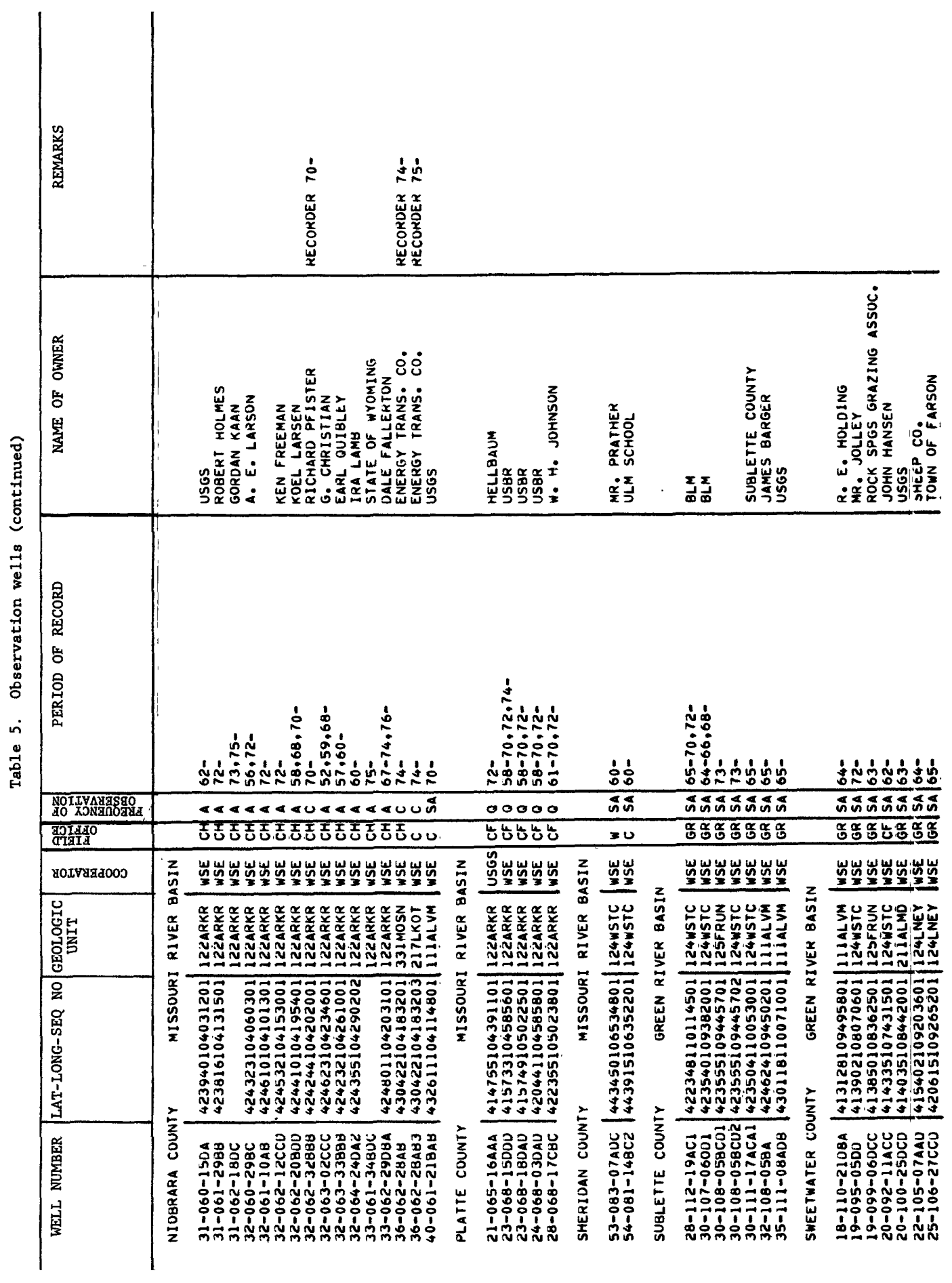




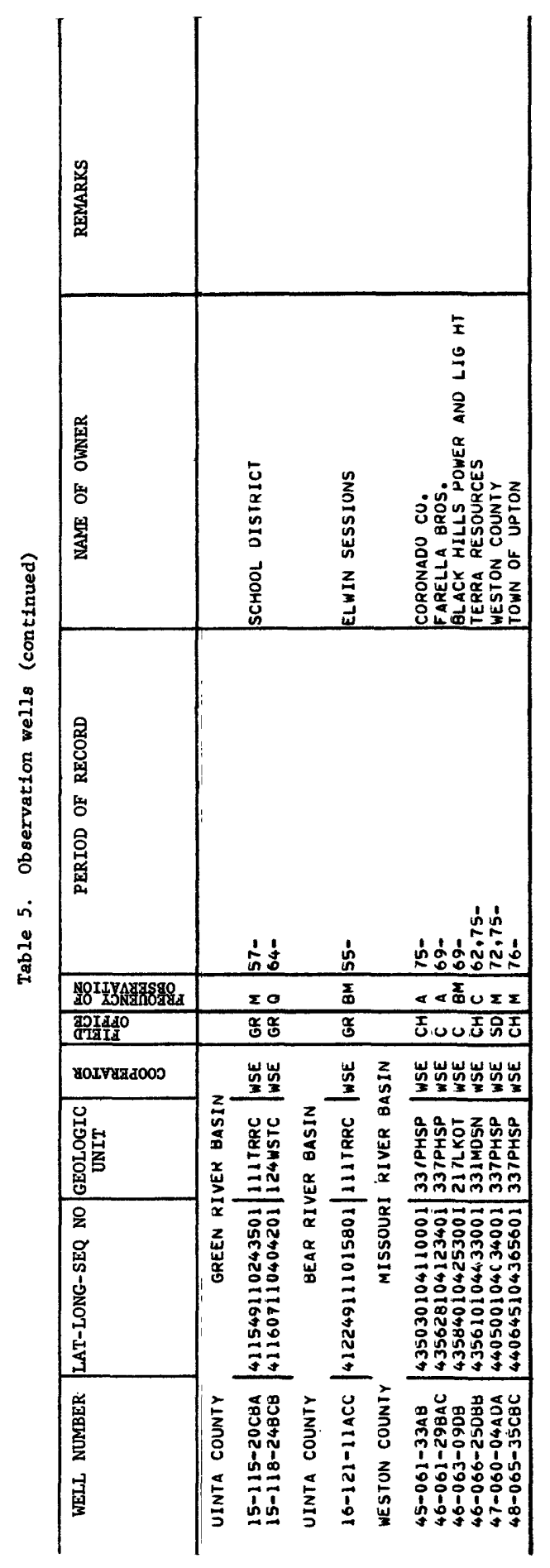




\section{WATER-RESOURCES APPRAISAL PROJECTS}

The numerous water-resources appraisal projects being made in Wyoming are described below. The areas of project activity are slown in figure 10 .

\section{Flood investigations in Wyoming}

$$
\text { (Project WY 59-010) }
$$

Funds: Wyoming Highway Department and U.S. Geologica1 Survey

The main objective is to obtain sufficient basic hydrologic data to define the magnitude and frequency of floods on a regional bas:s for the entire state and to publish the interpretative analyses in easily usable form. On request from the cooperator, flood-flow characteristics of streams at specific sites will be determined by studying such factors as: history of past floods; distribution of flow across the floodplain and main channel; and mean velocities in the main channel and overflow areas.

\section{Flood-hazard information, House Document 465}

(Project WY 73-022)

Funds: U.S. Federal Insurance Agency (HUD) and U.S. Geological Survey

The objective is to delineate flood-prone areas on U.S. Geolngical Survey $7 \frac{1}{2}{ }^{\prime}$ quadrangles and distribute copies of the maps to any one who can use them. Quadrangles selected are those covering major streams, with priority given to urban areas. The estimated 100-year flood is the basis for the delineation.

\section{Water resources of Weston County, Wyoming}

$$
\text { (Project WY 74-026) }
$$

Funds: Wyoming State Engineer and U.S. Geological Survey

The objectives are to determine: (1) The distribution (areally and vertically) and the thickness of each of the principal aquifers or aquifer systems; (2) the movement of water in each of the principal aquifers or aquifer systems; (3) the hydraulic characteristics for each principal aquifer or aquifer system; (4) the water-bearing properties of subordinate aquifers; (5) the volume of ground water in storage; (6) the quality of water in each aquifer; (7) the quantity of runoff from small watersheds; (8) the quality of runoff at gage sites; (9) the effect of ground-water withdrawal on water levels; and (10) to evaluate the potential for artificial recharge. 


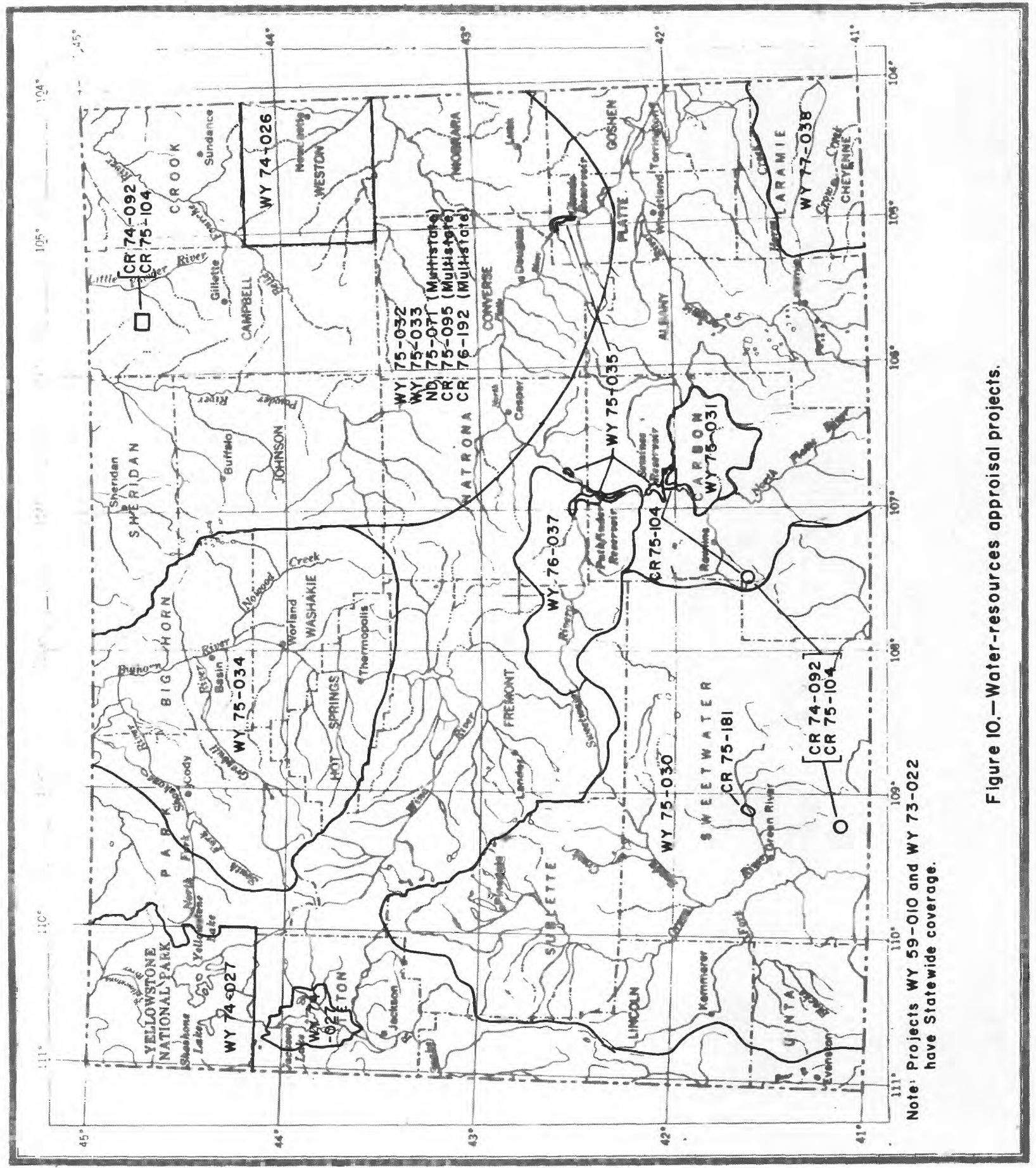


Monitoring waste-water effluent in Yellowstone and Grand Teton National Parks, Wyoming

(Project WY 74-027)

Funds: National Park Service and Teton County

The objectives are to determine: (1) Position of the water table and its relation to percolation ponds and nearby surface-water bodies; (2) the slope of the water table and thus the direction of movement of the effluent; (3) ground-water velocities and thus the time of travel of effluent from pond to surface-water body; (4) the vertical zone of movement of the effluent; and (5) baseline water quality in the shallow aquifers in the vicinity of the percolation ponds.

Water and its relation to economic development in the Green River and Great Divide basins in Wyoming

(Project WY 75-030)

Funds: U.S. Geological Survey, with basic-data support funds from U.S. Bureau of Land Management

The study is designed to gather information and make available to interested industrial, agricultural, and governmental people, interpretive reports that describe: (1) The distribution and quality of surface water in space and time; (2) relationships between surface water and ground water; (3) the distribution, quantity, and quality of ground water; and (4) hydrology-related aspects of the environment. Efforts of the study are directed toward: (1) Describing the water resources and hydrologic relationships that presently exist; (2) developing predictive methods that may be used to describe future conditions, including reactions to increased water development; and (3) establishing monitoring programs for detecting possible changes in water parameters.

Impacts of economic development and water use on water resources in the Hanna basin in Wyoming

(Project WY 75-031)

Funds: U.S. Geological Survey and U.S. Bureau of Land Management

The objectives of the project are to describe the present characteristics of the hydrologic environment, to monitor changes in it, and to evaluate the effects of those changes. On the surface, peak and annual flows, channel geometry, sedimentation rates, erosion rates, uses, and quality of water will be investigated. In the subsurface, aquifer characteristics, ground-water uses, and pumping amounts will be estimated. 
The approach will be to: (1) Describe streamflow conditions--evaluate past records, establish three gaging sites for flow measurements, sediment sampling, and chemical quality (use channel-geometry methods where necessary); and (2) define aquifer characteristics--perform aquifer tests, draw potentiometric maps, analyze water quality, and identify recharge and discharge areas. The three gaging stations, Hanna Draw near Hanna, North Ditch near Coyote Springs, and Big Ditch near Coyote Springs are included in the lists of streamflow, chemical-quality and sediment stations.

$$
\begin{aligned}
& \text { Water resources of the Powder River structural } \\
& \text { basin in Wyoming in relation to energy development }
\end{aligned}
$$

$$
\text { (Project WY 75-032) }
$$

Funds: U.S. Geological Survey, with basic-data support funds from U.S. Bureau of Land Management and U.S. Environmental Protection Agency

The study is designed to gather information and make available to industrial, governmental, and other interested people, intrepretive reports that describe the water supply in the area and the possible impact of planned development on the water resources.

A planning report was prepared during the first year of the projert, outlining the approach to be used in the study. Techniques included are those for determination of aquifer properties, streamflow analysis, channel geometry, isotope study, biological assay, water budgets, modeling, and geophysics.

\section{Hydrology of Paleozoic rocks in the Powder River basin and adjacent areas, northeastern Wyoming}

$$
\text { (Project WY 75-033) }
$$

Funds: U.S. Geological Survey

The project is designed to derive a conceptual model of the aquifer system to better predict the quantity and quality of water available from the Paleozoic rocks and to predict some of the effects of its development. Principal objectives are to determine: (1) The distribution, thickness and physical properties of the aquifer system; (2) processes that developed the present distribution of aquifer parameters in order to extend point data to other parts of the aquifer system; (3) the potentiometric surface and chemical quality of the water in the aquifer system; and (4) the effects of increased development of water from the aquifer system. 
Evaluation of selected Paleozoic and flood-plain aquifers

in the Bighorn basin, north-central Wyoming

(Project WY 75-034)

Funds: Wyoming State Engineer and U.S. Geological Survey

The primary objectives are: (1) To ascertain to the extent pcssible the safe yield of the aquifer system in the Paleozoic rocks without: causing a substantial decrease in the ground-water storage or a significant decrease in the amount of artesian pressure, and (2) to delineate areas of the flood-plain alluvium where additional well pumpage will not cause appreciable decrease in ground-water storage or affect the flow of streams adjoining the flood plains. The present study will be concentrated in the Ten Sleep area in the eastern part of the basin; based on results, recommendations will be made regarding additional studies elsewhere in the basin.

Algal-growth potential of principal

North Platte River reservoirs in Wyoming

(Project WY 76-035)

Funds: U.S. Geological Survey (Missouri River basin program)

Eutrophic conditions may be developing in one or more of the four major reservoirs on the North Platte River (Seminoe, Pathfinder, AJ.cova, and Glendo). Oxygen depletion could have an adverse effect on recreational use of the reservoirs and on fish habitat. Development of mineral resources, particularly coal mining, is taking place at locations adjacent to one of the reservoirs. There is no information about the presert state of algal growth with which to evaluate the seriousness of the probJem, to evaluate changes caused by mining activities, or to predict future trends.

The objectives of the study are to: (1) Determine the extent of algal growth in the four major reservoirs; (2) evaluate trends in algalgrowth potential, including effects of effluent from coal-mining activities adjacent to the reservoirs; and (3) determine the feasibility of developing a model for predicting algal growth.

The first three years will be devoted exclusively to data coliection, with analysis of data and preparation of a report scheduled for the fourth year. Vertical-profile water samples will be collected monthly (MayOctober) from a boat at sites above the dams and in the principal arms of each reservoir. Sampling will also be done twice each winter. Field parameters will include dissolved oxygen and temperature. Laboratory parameters will include $\mathrm{NH}_{4}, \mathrm{NO}_{2}+\mathrm{NO}_{3}, \mathrm{P}$, residue, and AGP. A set of phytoplankton samples wil1 $1^{4}$ e collected each year in early spring and in late summer for identification of genera. Graphical and statistical techniques, such as regression, will be used. 
Preliminary digital model of the Arikaree aquifer in the Sweetwater River basin, central Wyoming

(Project WY 76-037)

Funds: Wyoming State Engineer and U.S. Geological Survey

The objectives of this study are: (1) To develop a preliminary digital model of the Arikaree aquifer in the Sweetwater River basin; (2) to define the existing stream-aquifer relationship; and (3) to evaluate the feasibility of developing a comprehensive digital model of the Arikaree aquifer.

Quantitative study of the Tertiary aquifers in southern Laramie County, Wyoming

(Project WY 77-038)

Funds: Wyoming State Engineer, Wyoming Department of Economic Planning and Development, and U.S. Geological Survey

The objectives are to: (1) Determine the extent of ground-water development for irrigation, industry, and public supply and describe the effect of this development on water levels and stream discharge in the study area, and (2) provide a means of predicting the effects of alternative ground-water management decisions.

Availability of ground water from the Cretaceous and Tertiary aquifers of the Fort Union Coal Region

(Project ND 75-071)

Funds: U.S. Geological Survey

This investigation is a compilation of existing data from South Dakota, North Dakota, Montana, and Wyoming of the Tertiary rocks and aquifers overlying the Pierre Shale. The objectives of the investigation are: (1) To determine the location, extent, and nature of the aquifers and confining beds; (2) to evaluate the occurrence and movement of ground water, including the sources of recharge and discharge; and (3) to determine the chemical quality of the ground water. This project is being done by the North Dakota District, Water Resources Division, U.S. Geological Survey, headquartered in Bismarck, North Dakota. 
Runoff and sediment yield from rainfall simulation

(Project CR 74-092)

Funds: U.S. Geological Survey and U.S. Bureau of Land Management

During the summer of 1976 rainfall simulation studies were conducted at three EMRIA (Energy Mineral Rehabilitation Inverntory and Analysis) locations in Wyoming. These were at Potter Mountain near Rock Springs, Red Rim near Rawlins, and White Tail Butte near Recluse.

Simulated rainstorms of about 1.5 inches in 45 minutes were applied to small watersheds of about 3,000 square feet at eleven different sites within these study areas. The purpose of the studies was to characterize the hydrologic properties of undisturbed areas prior to mining. Runoff and sediment production from these simulated storms are being related to slope, vegetative cover, soil texture, root development, and antecedent moisture.

Plans for operations in Wyoming during 1977 are not definite.

$\frac{\text { Geochemical survey of waters of }}{\text { the western coal regions }}$

(Project CR 75-095)

Funds: U.S. Geological Survey

It is the goal of this project to efficiently provide data on the "natural" or pre-development geochemistry of the waters of the western coal regions, with particular emphasis on trace elements that may heve a relationship to health and disease in humans and animals.

To date, sampling and data interpretation of ground water in the Fort Union Coal Region has been completed. Sampling of ground water in the Powder River basin of Montana and Wyoming has been completed, but laboratory results are pending.

Reconnaissance techniques for evaluating the rehabilitation potential of energy lands

$$
\text { (Project CR 75-104) }
$$

Funds: U.S. Geological Survey and U.S. Bureau of Land Management

The Public Lands Hydrology Program is participating in EMRIA studies in cooperation with the BLM at four locations in Wyoming as the main activity of this project. The purposes are: (1) To provide baselire data in map and graphic form on vegetation, soil-vegetation-water relations, soil erodibility, and sediment yields; (2) to estimate what effect surface 
mining would have on the above parameters; and (3) to recommend measures for minimizing environmental damage if mining occurs. Data have been gathered at the following locations: Hanna study area near Hanna, Potter Mountain near Rock Springs, Red Rim near Rawlins, and White Tail Butte near Recluse. Contributions were made to an Inter-Agency administrative report on the Hanna study area which was released by BLM in 1975. Contributions to the Inter-Agency report for the Red Rim are in review. Contributions for the Potter Mountain and White Tail Butte reports will be prepared in 1977.

Another activity of this project is the preparation of a source-area sediment-yield map of the areas upstream of the outcrops of surfaceminable coal in Campbell County, Wyoming. The purpose of the map is to provide estimates of sediment yield from small watershed areas in order to have a baseline with which to assess possible changes in sediment yield caused by surface mining. The map will be based on sediment surveys of 21 stock reservoirs and characteristics of the associated watersheds in Campbell County, in addition to an earlier sediment-yield study in the Upper Cheyenne River basin of Wyoming. A draft map of the center one-third of Campbe11 County was prepared in 1976 and preparation of draft maps of the other two-thirds of the county is planned for late 1977.

A third activity of this project is a cooperative study with the Wyoming District, Water Resources Division and the Regional Geochemistry Branch, Geologic Division at the abandoned Hidden Water mine near Ranchester, Wyoming. The purpose of the study is to compare the sediment yield and geochemistry of a small unmined watershed and an adjacent watershed that was surface-mined about 25 years ago but never rehabilitated. Sediment surveys were completed in reservoirs at the mouths of the watersheds and samples were obtained of hillslope, channel and reservoir bottom material for particle size and elemental analyses in the fall of 1976. A report on this study will be prepared in 1977.

Sorption of residual organic substances in retort waters by spent oil-shale residues

(Project CR 75-181)

Funds: U.S. Geological Survey

The analytical techniques used to concentrate, separate, and classify natural organic solutes in water (Leenheer and Huffman, 1976) were scaled up and applied to aqueous-process wastes from oil-shale retorting operations such that gram-sized quantities of these waste organic solutes were isolated for further study. This large-scale separation was necessary for the study of the sorption of these waste organic solutes upon processed shale, soil, and sediment after disposal of the aqueousprocess wastes. The goal of this research is to provide the analytical methodology which can be used to provide the sorption parameters needed in organic-solute transport models of wastes in surface and ground water. 


\section{Hydrology of the Madison aquifer}

(Project CR 76-192)

Funds: U.S. Geological Survey

The objectives of the project are to evaluate the Madison Limertone and associated rocks as a source for water supplies and to provide the necessary information for an orderly development of the aquifer. Tlo study area includes 188,000 square miles in eastern Montana, westerr North and South Dakota, a small part of northwestern Nebraska, and rortheastern Wyoming. The Wyoming part comprises about 32,000 square miles.

During calendar year 1976, as a part of the regional evaluatior of the geology, hydrology, and geochemistry of the Madison aquifer, a 4,341-foot test well was completed and another test well to be drilled to a depth of about 9,800 feet was begun.

Madison Test Well No. 1, in section 15, T.57 N., R.65 W., Crook County, Wyo., was completed as a Precambrian test in October 1976. Twenty-two cores were taken at selected intervals and $16 \mathrm{dril1-stem}$ and packer tests were made. Geophysical logs available include electric., induction electric, gamma, guard, neutron, acoustic, density, 3-dimensional velocity, temperature, and caliper.

Madison Test We11 No. 2 was begun November 17, 1976. It is in section 18, T.1 N., R.54 E., Custer County, Mont. 
A 1isting of selected references of publications by the U.S. Geological Survey is given in the pamphlet "Water Resources Investigations in Wyoming, 1976". A more complete State 1ist of reports is given in a pamphlet "Geologic and Water-Supply Reports and Maps--Wyoming". Both pamphlets may be obtained free on application to the Wyoming District Office of the U.S. Geological Survey.

Listed below are additional selected references of recent publications not given in the pamphlets previously mentioned.

Hadley, R. F., and Keefer, W. R., 1975, Some potential effects of surface mining of the Wyodak-Anderson coal in the Gillette area, Campbell County, Wyoming: U.S. Geol. Survey Misc. Geol. Inv. Map I-848-F. Keefer, W. R., and Hadley, R. F., 1976, Land and natural resource information and some potential environmental effects of surface mining in the Gillette area, Wyoming: U.S. Geol. Survey Circ. 743, 27 p.

Leenheer, J. A., and Huffman, E. W. D., Jr., 1976, Classification of organic solutes in water using macroreticular resins: Jour. Research U.S. Geo1. Survey, v. 4, no. 6, p. 737-751.

Lusby, G. C., and Toy, T. J., 1976, An evaluation of surface-mine spoils area restoration in Wyoming using rainfall simulation: Earth Surface Processes, v. 1, p. 375-386. 